FOLIA HISTORICA CRACOVIENSIA, 22: 2016, s. 265-302

DOI: http://dx.doi.org/10.15633/fhc. 2082

Ryszard Mączyński

Uniwersytet Miko£aja Kopernika w Toruniu

\title{
Wiekopomna zasługa \\ i zakonna pokora - dzieje serca Stanisława Konarskiego
}

W krakowskim kościele pijarów zwraca uwagę pochodząca sprzed lat 130, ulokowana po prawej stronie prezbiterium, plastyczna oprawa miejsca złożenia serca Stanisława Konarskiego, zakonnika Szkół Pobożnych z xv III stulecia, a przy tym odważnego publicysty i reformatora szkolnictwa (il. 1).

Problematyka osobnego pochówku serca sławnego pijara nie była dotychczas przedmiotem głębszych rozważań. Najszerzej poruszył ją Jan Innocenty Buba w przesłanym do „Przekroju” artykule, co stanowiło odzew akcji podjętej w latach 8o. xx wieku przez redakcję tygodnika: „Gdzie są serca sławnych Polaków?”'. W późniejszym nieco czasie na tych informacjach oparty został stosowny fragment w popularnej publikacji Mieczysława Czumy i Leszka Mazana Poczet serc polskich ${ }^{2}$. Obfite natomiast okazują się źródła dotyczące okoliczności sprowadzenia serca Konarskiego z Warszawy i uroczystości złożenia go w krakowskim kościele Przemienienia Pańskiego. W archiwum pijarskim zachowały się między innymi dwa poszyty dokumentów odnoszących się do tego zdarzenia ${ }^{3}$, rozmaitych wiadomości na ten temat nie szczędziły ówczesne periodyki z „Tygodnikiem

Zob. J. Buba, Odważył się być mądrym, oprac. L. Mazan, „Przekrój” 39 (1983) nr 1973, s. 14.

2 Zob. M. Czuma, L. Mazan (współpraca M. Rożek), Poczet serc polskich, Kraków 2005, s. 270 .

3 Pierwszy z nich zawiera dokumenty i całą korespondencję dotyczącą tego wydarzenia: Archiwum Polskiej Prowincji Zakonu Pijarów w Krakowie (dalej: APPzP), rkps sygn. Col. Cracov. 92: Dokumenty odnalezienia $i$ pochowania $w$ Krakowie serca ks. Stanisława Konarskiego, passim. Drugi poszyt stanowi rękopiśmienna wersja przygotowanej przez pijarów i wydanej następnie drukiem okolicznościowej broszury: APPzP, rkps sygn. Col. Cracov. 93: Uroczystość pochowania serca śp. ks. Stanisława Konarskiego w kościele pijarów krakowskich, passim. 
Ilustrowanym” i „Bluszczem” na czele ${ }^{4}$, opublikowana też została specjalna broszura - Uroczystość pochowania serca śp. ks. Stanisława Konarskiego ${ }^{5}$.

Aby nakreślić okoliczności, które doprowadziły do owej uroczystości, należy przypomnieć, że rząd carski dokonał - w ramach represji po klęsce powstania styczniowego - ostatecznej kasaty zakonu pijarów na terenie zaboru rosyjskiego, co w przypadku Domu Warszawskiego przeprowadzone zostało w roku $1866^{6}$. Przypieczętował też ostatecznie słabnącą kondycję zakonu, pozbawionego gromadzonych przez dziesięciolecia źródeł dochodu, pozbawionego możliwości działania na edukacyjnej niwie, choć to stanowiło zasadniczy cel Szkół Pobożnych, pozbawionego wreszcie własnej siedziby - kościoła i wszystkich zabudowań przy ulicy Długiej w Warszawie - zabranej na potrzeby prawosławia, jako kara za krzewienie postaw patriotycznych i obywatelskich. Ostatnie 30 lat istnienia zakonu nieliczni już pijarzy spędzili - jak na ironię - w gmachach należących niegdyś do swego największego konkurenta - jezuitów. Z rozległej w czasach wolnej Rzeczypospolitej sieci placówek pijarskich po 100 latach narodowej niewoli ostał się jedynie - nie bez losowych zawirowań - Dom Krakowski księży pijarów z kościołem Przemienienia Pańskiego 7 .

Na początku 1882 roku tygodnik „Bluszcz” zamieścił następującą informację:

Od dawna w kołach literackich Warszawy opowiadano sobie, że serce Stanisława Konarskiego znajduje się w posiadaniu pana [Jakuba] Pika, optyka warszawskiego. Dwa lata temu powzięto myśl wydostania tej pamiątki z rąk prywatnych i umieszczenia jej w jednym z kościołów grodu podwawelskiego, w Krakowie wszakże nie uznano podówczas chwili za odpowiednią i za obopólną zgodą sprawa odłożona została na później.

4 Zob. Wiadomości literackie, artystyczne i naukowe, „Bluszcz” 17 (1882) t. 28, nr 6, s. 48, nr 8, s. 63; Protokół pomieszczenia serca Stanisława Konarskiego w kolegium ks.ks. pijarów w Krakowie, „Tygodnik Ilustrowany” 13 (1882) nr 319, s. 79.

5 Zob. Uroczystość pochowania serca śp. x. Stanisława Konarskiego pijara w kościele xx. pijarów krakowskich $w$ dniu 13 lutego 1882 roku, Kraków 1882, passim.

6 Szerzej na temat ostatnich lat działalności zakonu pijarów w Warszawie: R. Mączyński, Wina i kara. Powstaniowe i popowstaniowe losy warszawskich pijarów (1830-1866), [w:] Losy klasztorów i zbiorów poklasztornych $w$ okresie represji po upadku powstania listopadowego $w 1831$ roku, red. M. Derwich, [publikacja pokonferencyjna z 12-15.07.2012 w Rytwianach, w druku].

Zob. T. Chromecki, Krótki rys dziejów zgromadzenia Szkół Pobożnych, czyli oo. pijarów, Kraków 188o, s. 121n i passim. Najszersza dotychczas publikacja o tym domu zakonnym: A. Pitala, Kolegium pijarów w Krakowie, Kraków 1994, passim.

8 Wiadomości literackie, artystyczne..., dz. cyt., nr 6, s. 48. 
W międzyczasie trwała ożywiona wymiana korespondencji ponad granicami zaborów i krajów, w którą zaangażowany był Adam Słotwiński, przełożony kolegium krakowskiego, oraz wiele innych osób dokładających starań, by pamiątka ta znalazła się w miejscu godnym i bezpiecznym. Zainteresowanie sprawą, acz zróżnicowane, wykazywali luminarze polskiej literatury: Jadwiga Łuszczewska (Deotyma) (il. 2), Józef Ignacy Kraszewski (il. 3), Antoni Edward Odyniec czy Teofil Lenartowicz; ten ostatni we Florencji napisał nawet $\mathrm{z}$ okazji odnalezienia cielesnej pamiątki Konarskiego utwór poetycki, zatytułowany Złote serce (il. 4) ${ }^{9}$. Wreszcie na początku roku 1882 przystąpiono do realizacji zamierzenia.

Do przekazywanego daru Jakub Pik załączył list, napisany na papierze firmowym prowadzonego przez siebie Zakładu Fizyko-Mechanicznego przy ulicy Miodowej 497A (il. 5). Wspominając czas popowstaniowych represji i kasaty warszawskiego kolegium Szkół Pobożnych, wyjaśniał, jak owa szacowna pamiątka znalazła się w jego posiadaniu:

Kilku księży opuszczających kraj zwróciło się do mnie z żądaniem, abym zbiory te [pijarskie] zabrał, a z nimi serce oraz dokumenty dowodzące jego autentyczności. Na skutek tego żądania wszystkie oddane mi pamiątki wraz z sercem przyjąłem. Rzecz prosta, iż w czasach owych trzeba się liczyć było z warunkami politycznymi, a ja jako kupiec więcej od innych stosować się do nich musiałem. Dokument dowodzący autentyczności serca Konarskiego wraz z innymi manuskryptami został przeze mnie ukryty. Mam nadzieję, że odnaleźć go jeszcze będę w stanie. Obecnie dodaję tylko, iż wszystko, co tutaj napisałem jest świętą prawdą i pod przysięgą każdej chwili jestem zdecydowany to stwierdzić.

Podkreślał jeszcze: „Wszystko to przechowałem [...] dlatego, że przedmioty te były narodową pamiątką, które dla mnie, jako uczciwego obywatela-Polaka, chociaż Izraelity, były świętością" ${ }^{30}$.

Dar przywieziony do Krakowa 15 stycznia 1882 roku trzy dni później poddano szczegółowym oględzinom. Rektor Adam Słotwiński powołał do tego specjalną komisję z udziałem Józefa Łepkowskiego, cesarsko-królewskiego konserwatora zabytków krajowych (il. 6). Protokół posiedzenia odnotował:

9 Zob. APPZP, rkps sygn. 92, s. nlb. Szczególnie interesujący jest autograf owego poematu z naniesionymi własnoręcznymi poprawkami poety. Wydanie utworu staraniem pijarów nastąpiło w tym samym roku: T. Lenartowicz, Złote serce. Wiersz ku czci ks. pijara Stanisława Hieronima Konarskiego, Kraków 1882, passim.

${ }^{10}$ APPZP, rkps sygn. 92, s. nlb. Fragment owego listu przedrukowano w okolicznościowej broszurze: Uroczystość pochowania serca..., dz. cyt., s. 4n. 
Znaleziono szkatułkę drewnianą, czarno politurowaną, czworoboczną, wysoką $29 \mathrm{~cm}$, szeroką $12 \mathrm{~cm}$, ze szkłem z przodu [...]. Przez szkło widać wielkie serce wyrobione z metalu z wyrytym na nim napisem: COR / P. STANISLAI KONARSKI / E SCHOLIS PIIS / D. III AUGUSTI / MDCCLXXIII (il. 7, 8). Po odśrubowaniu jednej ścianki szkatułki i usunięciu szkła, dobyto serce z metalu białego, z którego otworem wyrdzewionym dobył Jegomość Ksiądz Słotwiński, rektor, owinięte w papierze serce wcale nieźle przechowane. Wewnątrz owej puszki w kształcie serca z metalu ulanej, nic się więcej nie znalazło. Pan Łepkowski, konserwator zabytków, rozważywszy przedstawione mu dokumenty oraz obejrzawszy dokładnie przedmiot, o którym rzecz, oświadczył, iż żadnej wątpliwości ulegać nie może autentyczność w tych wywodach poparta. Po czym ksiądz rektor Słotwiński obwinął serce w świeże płótno i to, jak przedtem, w skrzyneczce umieszczone zostało ${ }^{11}$.

Energicznie zakrzątnięto się wokół wyboru miejsca złożenia serca w kościele i stworzenia stosownej dlań oprawy plastycznej „w myśl planu podanego przez pana Józefa Łepkowskiego" ${ }^{12}$. W bocznej ścianie prezbiterium miała być wydrążona nisza, ujęta czarnomarmurowym profilowanym obramieniem, zamykana metalowymi drzwiczkami, opatrzonymi inskrypcją oraz ozdobionymi godłami pijarskiego zakonu (il. 9). Powyżej, na konsoli z rodowym herbem Gryf, chciano umieścić gipsowe popiersie Konarskiego. Portret wykonał rzeźbiarz Tadeusz Błotnicki ${ }^{13}$. Źródłem wiedzy o wyglądzie pijara musiała stać się dlań replika spiżowego biustu, będącego dziełem Andrzeja Le Bruna, powstałego z inicjatywy króla Stanisława Augusta, należącego do galerii zasłużonych mężów pomieszczonej w Sali Rycerskiej Zamku Królewskiego w Warszawie (il. 10) ${ }^{14}$. Artysta zapragnął wszakże stworzyć własną, odmienną nieco interpretację portretu Konarskiego ${ }^{15}$.

${ }^{11}$ APPZP, rkps sygn. 92, s. nlb. Fragmenty protokółu oględzin serca opublikowano w „Tygodniku Ilustrowanym”: Protokół pomieszczenia serca..., dz. cyt., s. 79; a także w broszurze: Uroczystość pochowania serca..., dz. cyt., s. 5n.

${ }_{12}$ APPZP, rkps sygn. 92, s. nlb. Inwentaryzacyjny opis zrealizowanego dzieła podaje m.in.: APPZP, rkps sygn. Col. Cracov. 207: Krótka historia założenia kolegium krakowskiego i inwentarz kościoła Przemienienia Pańskiego, s. 5on.

13 Podstawowe informacje o artyście podał: J. Derwojed, Błotnicki Tadeusz, [w:] Słownik artystów polskich i obcych w Polsce działających. Rzeźbiarze, malarze, graficy, t. 1, Wrocław 1971, s. 186n.

${ }^{14}$ Praca Le Bruna ma obszerną literaturę, którą zestawiają najnowsze opracowania, m.in.: K. Mikocka-Rachubowa, André Le Brun, „pierwszy rzeźbiarz” króla Stanisława Augusta, t. 2, Warszawa 2010, s. 195n; A. Badach, Rzeźba. Katalog zbiorów. Zamek Królewski w Warszawie. Fundacja Zbiorów im. Ciechanowieckich. Fundacja Teresy Sahakian, Warszawa 2011, s. 42.

15 Szerzej na temat obu dzieł rzeźbiarskich i ich wzajemnej relacji: R. Mączyński, Konterfekty zwielokrotnione. Rozważania nad wizerunkami pijara Stanisława Konarskiego, Toruń 2014, s. 135n. 
Zachowując rysy twarzy, starał się ją odmłodzić, wyraźnie zarazem tuszując otyłość (il. 11). Jednak nawet fryzura została powtórzona za wzorem Le Bruna, a najistotniejsza modyfikacja sprowadziła się do zmiany nakrycia głowy - okrągłą piuskę zastąpił bardziej wyrazisty biret. Nie udało się za to przejąć z wyjściowego modelu młodzieńczego ducha Konarskiego, wyrażającego się w bacznym, przenikliwym spojrzeniu.

Ceremonialne złożenie serca odbyło się 13 lutego 1882 roku $^{16}$. Rano przybyłych powitał Adam Słotwiński, rektor Domu Krakowskiego, wyjaśniając cel przygotowanej uroczystości. Następnie cielesna partykuła z pijarskiego kolegium przeniesiona została procesjonalnie „przez wychowańców konwiktu pijarskiego, w licznej asystencji duchowieństwa świeckiego i zakonnego, tudzież licznie zgromadzonej publiczności” i wprowadzona do kościoła, gdzie umieszczono ją „na skromnym katafalku otoczonym zielenią i światłem”. Mszę - $\mathrm{z}$ asystencją chóru katedralnego - celebrował kanonik Wawrzyniec Centt, penitencjarz w kościele Mariackim. Po jej zakończeniu pijar Tadeusz Chromecki, magister nowicjatu, wygłosił mowę, w której nakreślił wiekopomne zasługi Stanisława Konarskiego ${ }^{17}$. Następnie „zdjęto serce z katafalku i zaniesiono do miejsca, w którym miało być umieszczone", po czym delegacja akademików lwowskich złożyła wieniec laurowy, ozdobiony szarfą ze stosownym napisem. Po południu odbył się jeszcze „wieczorek muzykalno-deklamacyjny”, mający stanowić dopełnienie i zakończenie uroczystości (il. 12). Pewnym zgrzytem była jednak odmowa uczestnictwa w niej przez intelektualistów krakowskich. „Akademia i Uniwersytet - pisano trzymały się z dala, oczywiście nie z żadnych innych pobudek, tylko z braku przeświadczenia o prawdziwości i tożsamości pamiątki” ${ }^{18}$. Głównymi animatorami zwątpienia byli literaturoznawcy: Karol Estreicher i Stanisław Tarnowski.

Pamiątka, będąca partykułą ciała Stanisława Konarskiego, nasuwa trzy pytania o charakterze zasadniczym. Pytanie pierwsze brzmi: czy zawarte w puszce serce jest autentycznym sercem Stanisława Konarskiego?

Ta właśnie kwestia w największym stopniu zaprzątała uwagę współczesnych. Pojawiała się nieustannie w przesyłanej korespondencji. Rektor Słotwiński

W późniejszym czasie Tadeusz Błotnicki był autorem dwóch jeszcze innych krakowskich podobizn pijara: jedna trafiła do galerii portretowej zasłużonych w parku Jordana (1892 lub 1893), druga ozdobiła schody prowadzące do kościoła Przemienienia Pańskiego (1899).

${ }^{16}$ Opis przebiegu uroczystości podawała okolicznościowa broszura - i ta rękopiśmienna: APPZP, rkps. sygn. 93, k. 4n; i ta drukowana: Uroczystość pochowania serca..., dz. cyt., s. 7n.

${ }_{17}$ Całe przemówienie Tadeusza Chromeckiego trafiło do okolicznościowego druku, jest zachowane zarówno w wersji rękopiśmiennej (ale bez ostatniej karty), jak i drukowanej.

18 Wiadomości literackie, artystyczne..., dz. cyt., nr 8, s. 63. 
pragnął mieć całkowitą pewność co do prawdziwości prochów zawartych w otrzymanej puszce. Jakub Pik tłumaczył się gęsto, że dokumenty potwierdzające autentyczność pamiątki były, ale mu zaginęły. Już to budziło daleko posuniętą ostrożność (a nieufność wzmagało żydowskie pochodzenie ofiarodawcy). Brak tego „autentyku” ostatecznie przed publicznością próbowano zakamuflować, dość wykrętnym zdaniem:

Dokument, o którym pan Pik wspomina, obecnie publikowany być nie może, gdyż imię osoby, która panu Pikowi doręczyła serce wraz z innymi zbiorami gabinetu fizycznego pijarskiego, zmilczanym być musi. Szczerość i bezinteresowność pana Pika dostatecznym jest w tym względzie dowodem ${ }^{19}$.

Kontrowersje co do autentyzmu szczątków dotarły jednak do galicyjskiej społeczności i położyły się - o czym wspomniano - cieniem na przygotowanej przez pijarów uroczystości.

Największy jednak niepokój wzbudzał fakt, że przepatrzenie dostępnych archiwaliów i druków nigdzie nie potwierdziło, że dokonano resekcji serca przed pochówkiem ciała. Nie ma o tym mowy ani w kronice Historia Domus Varsaviensis pod rokiem 1773, kiedy odnotowano zgon i pogrzeb sędziwego i schorowanego już Stanisława Konarskiego, ani w pijarskiej księdze Matricula, notującej informacje o wszystkich zakonnikach polskiej prowincji Szkół Pobożnych, ani w drukowanym nekrologu, zawierającym biograficzną faktografię, wklejanym następnie do prowadzonej w każdym kolegium Libri suffragiorum ${ }^{20}$. Nie wspomniano o tym w notatce prasowej, donoszącej o śmierci pijara, ani w kazaniu pogrzebowym, które sławiło jego dokonania i zasługi ${ }^{21}$. Nie pojawiła się też jakakolwiek na ten temat wzmianka w najstarszych życiorysach Stanisława Konarskiego spisywanych przez: Wojciecha Jakubowskiego (1778), Dymitra Michała Tadeusza Krajewskiego (1783), Franciszka Ksawerego Dmochowskiego (1803), Szymona Bielskiego (1812)

19 Analogiczne sformułowanie pojawia się w obu wersjach relacji - i tej rękopiśmiennej: APPZP, rkps. sygn. 93, k. 4; i tej drukowanej: Uroczystość pochowania serca..., dz. cyt., s. 7.

${ }^{20}$ Zob. Historia Domus Varsaviensis Scholarum Piarum, oprac. L. Chmaj, Wrocław 1959, s. 119n; APPZP, rkps sygn. AP V-1/1 (dawna sygn. S-1): Matricula Provinciae Polonae Scholarum Piarum 1742-1867, k. 16; APPZP, rkps sygn. Col. Lov. 3: Liber suffragiorum Loviciensis 1657-1781, s. 212n.

${ }^{21}$ Zob. „Wiadomości Warszawskie” 9 (1773) nr 62 (z 4 virI, suplement), s. nlb.; G. Zachariasiewicz, Kazanie [...] miane na pogrzebie x. Stanisława Konarskiego, Scholarum Piarum, dnia 5 sierpnia roku 1773, [Warszawa 1773], passim. 
czy Jana Chrzciciela Albertrandiego (1817), a zatem przez osoby, które obracały się w środowisku stołecznym i dobrze znały zmarłego pijara ${ }^{22}$.

Nie dysponując pisemnym potwierdzeniem autentyczności, szukano potwierdzenia w ludzkiej pamięci. Dowodu dostarczył Franciszek Kasterski, ostatni prowincjał pijarskiego zgromadzenia (il. 13). W liście z 24 stycznia 1882 roku przesłanym do rektora Adama Słotwińskiego z Błonia pod Warszawą, gdzie podówczas był proboszczem, napisał:

Serce Konarskiego umieszczone było w murze kościoła pijarskiego przy ulicy Długiej, o ile sobie po tylu odległych latach przypomnieć mogę, przy wejściu z zakrystii do bocznej nawy kościoła. Czy w roku, 1834 przy przenoszeniu do kościoła i kolegium pojezuickiego wszystkich sprzętów kościelnych i ruchomości pijarskich, było stamtąd wydobyte lub nie, tego wiedzieć nie mogę, bo wtenczas już nie byłem w Warszawie. Ponieważ w kolegium pojezuickim nie słyszałem nigdy o sercu księdza Konarskiego, żeby się tam gdzie znajdowało, nadto ponieważ medale dane temu księdzu Konarskiemu i księdzu Kopczyńskiemu umieszczono w murach kościoła pojezuickiego, to tym bardziej serce księdza Konarskiego byłoby umieszczone ${ }^{23}$.

Argumenty to słabe, pierwsze zdanie obwarowane jest zastrzeżeniem, drugie deklaruje niewiedzę, trzecie zaś stanowi domysł jedynie. „List ten - stwierdzano podczas trwania uroczystości złożenia serca - zachowany obecnie $\mathrm{w}$ archiwum kolegium krakowskiego księży pijarów, uznany został przez księdza biskupa krakowskiego [Albina Dunajewskiego] za dostateczny [...] dowód”"24.

Ważnym potwierdzeniem prawdomówności Jakuba Pika stało się późniejsze zeznanie Ignacego Koperskiego złożone w Dąbrowicach 9 lutego 1885 roku (il. 14).

W czasie wakacji, o ile przypomnieć sobie mogę w roku 1863, jako klerykom polecono nam uporządkowanie biblioteki tak zwanej żoliborskiej i spisanie katalogów.

${ }^{22}$ Zob. W. Jakubowski, Życie Stanisława Konarskiego, S[cholarum] P[iarum], krótko zebrane..., [w:] S. Konarski, Wiersze wszystkie z łacińskich na polskie przełożone, Warszawa 1778, s. nlb.; [D. M. T. Krajewski], Pochwała Stanisława Hieronima Konarskiego, Warszawa 1783, passim; [S. Bielski], Vita et scripta quorundam e Congregatione Cler[icorum] Reg[ularium] Scholarum Piarum in Provincia Polona professorum, qui operibus editis patriae et ecclesiae proficuis nomen suum memorabile fecerunt, Varsaviae 1812, s. 51n; J. C. Albertrandi, Opisanie medalu Stanisława Konarskiego z wykładem historyczno-krytycznym czynów i dzieł tego męża, „Dziennik Wileński” 6 (1817), s. 633n.

${ }^{23}$ APPZP, rkps sygn. Col. Cracov. 92, s. nlb.

${ }^{24}$ Analogiczne sformułowanie pojawia się w obu wersjach relacji - i tej rękopiśmiennej: A PPZP, rkps. sygn. 93, k. 4; i tej drukowanej: Uroczystość pochowania serca..., dz. cyt., s. 6. 
Biblioteka ta, odłączona od znacznie liczniejszej wojewódzkiej, mieszczącej się w oddzielnych salach, złożona była w dwóch pokojach i jednej sali na trzecim piętrze [...] kolegium.

Mowa o gmachu kolegium pojezuickiego, użytkowanego podówczas przez pijarów, położonego przy ulicy Jezuickiej.

W tej to sali - wspominał - złożone były resztki gabinetu fizycznego i na środkowym dużym stole, między różnymi narzędziami tegoż gabinetu stała puszka z sercem Stanisława Konarskiego. Gabinet ten po supresji w Królestwie Polskim pijarów sprzedany został przez księdza prowincjała Kasterskiego panu Pikowi, a otrzymane zań pieniądze rozdano nam klerykom, jako zasiłek na pierwsze potrzeby po zniesieniu wspólnego stołu i utrzymania. Że więc wraz ze wspomnianym gabinetem i puszkę z sercem Konarskiego, jako między innymi puszkami, pudełkami, maszynami, narzędziami fizycznymi umieszczono, to zdaje się nie ulegać zaprzeczeniu ${ }^{25}$.

Mimo sygnalizowania tych wszystkich wątpliwości, jakie wywoływała sprawa prawdziwości przekazanego pijarom serca, nie wydaje się, by dzisiaj autentyczność szczątków zawartych w puszce złożonej w pijarskim kościele w Krakowie miała wzbudzać jakiekolwiek kontrowersje. Nie ulega kwestii, że szczątki są autentyczne (choć oczywiście ostatecznego rozstrzygnięcia mogłyby dostarczyć przeprowadzone badania DNA). Realizacja ukazu likwidacji warszawskiego kolegium pijarów spowodowała, że majątek zakonny w znacznej swej części został rozprowadzony w nie całkiem jasnych okolicznościach, a rozmaite pochodzące zeń przedmioty trafiały w ręce prywatne. Potwierdzić to mogą losy zarówno portretów zakonników pijarskich, jak też ksiąg z zasobów ich bibliotek, tej należącej niegdyś do konwentu Collegium Regium i tej stanowiącej własność konwentu Collegium Nobilium ${ }^{26}$. Jest zatem całkiem prawdopodobne wyjaśnienie, że puszka $\mathrm{z}$ sercem Konarskiego trafiła do rąk Pika wraz z rozmaitymi narzędziami z muzeum fizycznego.

Sam zresztą ofiarodawca może być gwarantem autentyczności pamiątki i prawdziwości swych zeznań ${ }^{27}$. Był bowiem dobrze spolonizowanym mieszkańcem

25 Appzp, rkps sygn. Col. Cracov. 92, s. nlb.

${ }^{26}$ Na temat losów portretów: R. Mączyński, Konterfekty zwielokrotnione..., dz. cyt., s. 66n; na temat losów ksiąg: R. Mączyński, Warszawskie biblioteki księży pijarów, „Rocznik Historii Sztuki” 23 (1998), s. 130n.

${ }^{27}$ Podstawowe informacje podaje: S. Konarski, Pik Jakub, [w:] Polski słownik biograficzny, t. 26, Wrocław 1981, s. 219 n. 
Warszawy, cieszącym się szacunkiem jako uczciwy obywatel i zaufaniem jako rzetelny rzemieślnik i kupiec. Pragnął też upamiętnić swą zasługę, fundując elegancką drewnianą szkatułkę na pomieszczenie cennego depozytu, opatrując ją inskrypcją wypisaną na kości słoniowej: „Dar Jakuba Pika w Warszawie 1882 roku”. Zawartość znajdująca się wewnątrz puszki to dzisiaj jedyna zachowana cielesna partykuła Stanisława Konarskiego. Jego doczesne szczątki złożone w podziemiach kościoła przy ulicy Długiej podzieliły los wielu innych pochowanych tam - znanych i zasłużonych - zakonników Szkół Pobożnych ${ }^{28}$. Po usunięciu w 1834 roku pijarów z ich siedziby, decyzją generała Eugeniusza Gołowina, dyrektora Komisji Rządowej Spraw Wewnętrznych, Duchownych i Oświecenia Publicznego, podziemia zostały opróżnione z trumien, które wywieziono na cmentarz Powązkowski i pogrzebano we wspólnym grobie, nawet go nie oznaczając. Toteż już w połowie XIX wieku Kazimierz Władysław Wójcicki zauważał ze smutkiem, że „nie ma tu [...] najmniejszego śladu dla uwiecznienia ich pamięci”29.

W niewielkim tylko stopniu współczesnych zajmowało inne - wcale nie mniej intrygujące - pytanie: jakie przesłanki spowodowały, że z ciała Konarskiego wyjęto serce? Wskazać w tym przypadku należy trzy czynniki.

Pierwszy z nich to szczególna waga wiązana z tym właśnie najistotniejszym organem ludzkiego ciała, gdzie znajduje się siedlisko wszelkich uczuć, a także jak twierdzili niektórzy - siedziba ludzkiej duszy. Pijarzy istotnie przyczynili się do rozpropagowania kultu Najświętszego Serca Jezusowego ${ }^{30}$. Cześć ową zapoczątkowała cudowna wizja siostry wizytki Małgorzaty Marii Alacoque. Uwielbienie dla Serca Jezusa spontanicznie przyjęte przez wiernych, propagowane przez niektóre zakony, zwłaszcza wizytek, pijarów i jezuitów, z rezerwą i ostrożnością traktowane było przez władze kościelne. Przywilej na wprowadzenie takiego nabożeństwa i organizację bractwa udzielany był indywidualnie przez Rzym poszczególnym świątyniom czy zgromadzeniom. Warszawscy pijarzy otrzymali je jako jedni z pierwszych już w 1705 roku. Stało się to dzięki energicznym działaniom członka tego zakonu Paulina Wiązkiewicza, nota bene kapelana stołecznych

${ }^{28}$ R. Mączyński, Zespoły architektoniczne Collegium Regium i Collegium Nobilium warszawskich pijarów 1642-1834, Warszawa 2010, s. 163n.

${ }_{29}$ K. W. Wójcicki, Cmentarz Powązkowski pod Warszawa, t. 2, Warszawa 1856, s. 94. Tablicę $\mathrm{w}$ pobliżu tego miejsca umieszczono dopiero w 1964 roku.

${ }^{30}$ Szerzej na ten temat: J. Buba, Początki czci publicznej Serca Bożego, [w:] Pijarzy w kulturze dawnej Polski. Ludzie i zagadnienia, Kraków 1982, s. 48n; C. Drążek, Rozwój kultu Serca Jezusa w Polsce, [w:] Bóg bliski. Historia i teologia kultu Najświętszego Serca Jezusa, Kraków 1983, s. 11n; Culto a Corazón de Jesús, [w:] Diccionario enciclopedico escolapio, t. 5: Escolapios en Polonia y Lituania, coord. L. M. Bandrés Rey, Salamanca 1985, s. 78n. 
sióstr wizytek, który zasłynął jako kultu Serca Jezusowego „wielki promotor” i autor poświęconej mu obszernej rozprawy o wymownym tytule Skarb nowy dotąd niewiadomych łask i nieznanych dobrodziejstw, wydanej w roku 1706, później wielokrotnie wznawianej (il. 15) $)^{31}$. O funkcjonowaniu bractwa przy warszawskim kościele Szkół Pobożnych źródła informowały jeszcze w czasach, gdy nastąpiła śmierć Konarskiego.

Szczególna adoracja Najświętszego Serca Jezusowego zaowocowała też przychylnością pijarów wobec praktykowanego zwyczaju osobnych pochówków serc osób świeckich i duchownych - to czynnik drugi. Idea ta, zapoczątkowana już w starożytności, odrodziła się i spopularyzowała w dobie nowożytnej ${ }^{32}$.

Wszedł też zwyczaj - pisano w XIX stuleciu - wydzierania serc z ciał zmarłych i chowania ich oddzielnie w urnach lub złotych i srebrnych pudełkach, po kościołach lub nawet domach. Zwykłym to było obyczajem, gdy zwłoki balsamowano, ale i bez tego trafiało się niekiedy $\mathrm{z}$ afektacji i przesady wychodzącej za granice delikatniejszego poczucia $^{33}$.

Do schyłku wieku Xviı postępowano tak w Rzeczypospolitej przede wszystkim z królami, królowymi, a także członkami ich najbliższej rodziny. Dopiero w XVIII stuleciu zwyczaj ten zaczęto stosować wobec dostojników duchownych i świeckich, apogeum zaś popularności zjawiska nastąpiło około połowy tego wieku. Jednak przykłady zebrane z całej Rzeczypospolitej pokazują, że zwyczaj

${ }^{31}$ P. Wiązkiewicz, Skarb nowy dotąd niewiadomych łask i nieznanych dobrodziejstw Najświętszego Serca Jezusowego w roku 1705 dnia 30 maja $z$ wielkimi i osobliwymi odpustami przez [...] Klemensa XI nadanymi [...] w kościele warszawskim xx. Scholarum Piarum [...] wiernym otworzony, Warszawa 1734, passim.

${ }^{32}$ Zagadnienie to ciągle czeka na naukowe opracowanie. Dotychczas ogłoszone drukiem prace albo mają charakter rozpoznawania tematu: A. Badach, Pogrzeby serc na ziemiach wschodnich Rzeczypospolitej w XVIII wieku. Wprowadzenie do zagadnienia i postulaty badawcze, [w:] Sztuka ziem wschodnich Rzeczypospolitej XVI-XVIII wieku, red. J. Lileyko, Lublin 2000, s. 639n; albo podejmują zagadnienia szczegółowe, jak choćby: J. Nieciecki, Materiały do pomnika serca Jana Klemensa Branickiego w Białymstoku, [w:] Studia nad sztuka renesansu i baroku, t. 8: Fundator i dzieło w sztuce nowożytnej, cz. 3, red. J. Lileyko, I. Rolska-Boruch, Lublin 2007, s. 169n; A. S. Czyż, O pochówkach serc Michała Korybuta Wiśniowieckiego i Klary Izabelli de Mailly-Lascaris Pacowej oraz nekropoli Paców w Pożajściu, „Biuletyn Historii Sztuki” 75 (2013) nr 4, s. 671n. Popularną formę ma - wspomniana już uprzednio - publikacja: M. Czuma, L. Mazan (współpraca M. Rożek), Poczet serc polskich, dz. cyt., passim.

${ }_{33}$ X. S. Ch. [S. Chodyński], Pogrzeb, [w:] Encyklopedia kościelna, t. 2o, red. M. Nowodworski, Warszawa 1894, s. 140. 
ów nigdy nie dotyczył zakonników, w ich wypadku bezwzględnie obowiązywała zasada skromności ${ }^{34}$.

Trzeba zauważyć, że do owej popularności pochówków serc istotnie przyczynił się sam zakon pijarów. Najlepiej poświadcza to rzeszowski kościół zgromadzenia pozostający pod opieką rodu Lubomirskich. Złożone tam zostały serca: Hieronima Augustyna Lubomirskiego, hetmana wielkiego koronnego (1706), Jana Kazimierza Lubomirskiego, starosty bolimowskiego (1737), a wreszcie Jerzego Ignacego Lubomirskiego, pisarza polnego koronnego (1753) (il. 16) $)^{35}$. Z kolei w łowickim kościele Szkół Pobożnych pochowano serce prymasa Krzysztofa Antoniego Szembeka $(1746)^{36}$. Doniosłą rolę w propagowaniu tej mody odegrał również warszawski kościół pijarów. W 1746 roku umieszczono w nim serce wojewody krakowskiego Teodora Lubomirskiego (ciało spoczęło w podwarszawskim Czerniakowie), w roku zaś 1750 - serce Jana Tarły, wojewody sandomierskiego (ciało pochowano w Opolu Lubelskim) ${ }^{37}$. Obu ceremoniom towarzyszyły druki wydane przez stołeczną oficynę Szkół Pobożnych, szczegółowo opisujące niezwykle okazałe dekoracje, jakie tworzyły oprawę tych solennych uroczystości ${ }^{38}$. Zwyczaj osobnego grzebania serc stanowił pochodną życzenia wyrażonego w testamencie zmarłego, działań egzekutorów jego ostatniej woli oraz przyzwolenia

34 Ale ceniono rozmaite "cielesne pamiątki” po zmarłych zakonnikach. Dowodem tego może być - nigdy dotąd niewzmiankowane - zachowanie się w pijarskich zbiorach kosmyka włosów Atanazego Pomorzkanta: APPzP, rkps sygn. RAC 10: Dokumenty dotyczące pijarów warszawskich, dok. 4. Pakiecik, który je skrywa, opatrzony został napisem: „Dnia 6 maja roku 1823 o godzinie trzy kwadranse na pierwszą po południu umarł śp. x. Atanazy Pomorzkant w 88 roku życia swego. Włosy w tym papierku obciąłem po jego śmierci na miłą dla mnie pamiątkę".

${ }_{35}$ Pisali o nich, reprodukując ich fotografie: M. Czuma, L. Mazan (współpraca M. Rożek), Poczet serc polskich, dz. cyt., s. 132n, 182n, 212n. Nie wspomniał natomiast o tych zabytkach autor najnowszej monografii rzeszowskiego kolegium pijarów (tamże wymienione starsze jego publikacje): J. Świeboda, Pijarzy w Rzeszowie w XVII-XVIII wieku, Kraków 2012, s. 11.

${ }^{36} \mathrm{~W}$ tym przypadku - co nieczęste - znany jest twórca epitafium; w 1759 roku wykonał je złotnik Franciszek Gnuszewicz: J. Gajewski, Sztuka w prymasowskim Łowiczu, [w:] Łowicz, dzieje miasta, red. R. Kołodziejczyk, Warszawa 1986, s. 556n; M. Czuma, L. Mazan (współpraca M. Rożek), Poczet serc polskich, dz. cyt., s. 202n.

${ }_{37}$ Niestety ani jedno, ani drugie epitafium nie przetrwało do obecnych czasów: R. Mączyński, Zespoły architektoniczne..., dz. cyt., s. 167n. Tylko pochówek serca Lubomirskiego został wspominany w: M. Czuma, L. Mazan (współpraca M. Rożek), Poczet serc polskich, dz. cyt., s. 190.

${ }_{38}$ Zob. Relacja o depozycji serca Jaśnie Oświeconego Księcia Jegomości Teodora Lubomirskiego, wojewody krakowskiego, [...] przy solennych egzekwiach w kościele warszawskim xx. Scholarum Piarum, [Warszawa 1745], passim; Relacja z pogrzebu serca [...] Jaśnie Wielmożnego Jegomości Pana Jana Tarła, wojewody sandomierskiego, w kościele warszawskim xx. Scholarum Piarum, [Warszawa 1750], passim. 
pijarskich zakonników; stosowano go tylko wobec wyjątkowych i szczególnie hojnych dobrodziejów zakonu.

I wreszcie czynnik trzeci, najważniejszy - ziemska zasługa. Casus serca Stanisława Konarskiego dowodzi, że w opozycji wagi wiekopomnych zasług i ślubów zakonnej pokory zwyciężyły zasługi. Jeszcze za życia Konarskiego doskonale zdawano sobie z nich sprawę ${ }^{39}$. Wydanie zbioru polskich praw Volumina legum obligujące do skrupulatnego ich przestrzegania, bezprzykładna odwaga domagania się gruntownej reformy Rzeczypospolitej i odrzucenia szkodliwej zasady liberum veto, bezkompromisowość walki o jasność i logiczność wypowiedzi i zawartych w nich myśli, zreformowanie szkolnictwa zakonnego (tak pijarskiego, jak i - poprzez oddziaływanie wzoru - jezuickiego) w kierunku przyswajania wiedzy użytecznej oraz umiejętności samodzielnego jej pogłębiania, propagowanie postaw głębokiego umiłowania ojczyzny i wpajanie młodzieży cnót obywatelskich - to tylko najważniejsze dokonania pijara. Uhonorował je w 1771 roku król Stanisław August specjalnie na cześć Konarskiego wybitym złotym medalem portretowym, z jakże wymowną sentencją: Sapere auso - „Temu, który odważył się być mądrym" ${ }^{\circ}$.

Śmierć Stanisława Konarskiego 3 sierpnia 1773 odbiła się szerokim echem w całej Rzeczypospolitej. Powstały liczne okolicznościowe utwory poetyckie, wyrażające żal po zmarłym oraz sławiące jego dokonania i zasługi ${ }^{41}$. Pisali je zarówno najwięksi ówcześni poeci - Ignacy Krasicki czy Franciszek Dionizy Kniaźnin - jak również, ci pomniejsi, okazjonalnie sięgający po pióro. Pogrzebowi Konarskiego towarzyszyła okazała celebra, z pewnością skromniejsza aniżeli magnacka, lecz

39 Zasługi te wielokrotnie były opisywane i analizowane w monografiach poświęconych zasłużonemu pijarowi, m.in.: W. Konopczyński, Stanisław Konarski, Warszawa 1926, passim; W. J. Rose, Stanislas Konarski. Reformer of Education in Xvirth Century Poland, London 1929, passim; J. Nowak-Dłużewski, Stanisław Konarski, Warszawa 1951, passim; B. Suchodolski, Stanisław Konarski, [w:] Z dziejów polskiej myśli filozoficznej i społecznej, t. 2: Wiek XVIII - oświecenie, red. B. Suchodolski, Warszawa 1956, s. 72n; L. Słowiński, Odważni mądrością. O reformatorach edukacji i nauki polskiej w dobie oświecenia, Poznań 1988, s. 11n; Z. Goliński, Stanisław Konarski (170o-1773), [w:] Pisarze polskiego oświecenia, t. 1, red. T. Kostkiewiczowa, Z. Goliński, Warszawa 1992, s. 13n; T. Chachulski, Stanisław Konarski, Warszawa 2000, passim; S. Żak, Ksiądz Stanisław Konarski (pisarz - pedagog - polityk), Kielce 2001, passim.

${ }^{40}$ R. Mączyński, Medale zasłużonych pijarów, „Rocznik Warszawski” 20 (1988), s. 19on; R. Mączyński, Konterfekty zwielokrotnione..., dz. cyt., s. 144n.

${ }^{41}$ Szerzej tę problematykę poruszali: R. Stępień, Ks. Stanisław Konarski w opinii niektórych współczesnych mu Polaków, [w:] Studia z dziejów oświaty XVIII-XX wieku, red. M. Chamcówna, Wrocław 1993, s. 3on; H. Bogdziewicz, O ks. Stanisławie Konarskim i innych pijarach w poezji, Kraków 2000, s. 9 n. 
wystawna jak na zakonnika. Ważniejsze zresztą niż ona były ważkie słowa, które wtedy padły z ust kaznodziei. Był nim Grzegorz Zachariasiewicz. W swej homilii, wspominając złoty numizmat pijara, oznajmił:

Gdyby mi tedy z wami tu naradzać się przyszło, jakim by też nagrobkiem uczcić należało zwłoki [tego] wielkiego męża [...], zdaje mi się, iżbyście wszyscy jednomyślnie przystali ze mną na to, aby ów medal, o którym się rzekło, wyobrazić nad grobem jego $\mathrm{z}$ tymże samym napisem: Auso sapere, [gdyż] nic nad to wspanialszego, nic szlachetniejszego nie trzeba do uwieńczenia i mądrej a wielkomyślnej w nagradzaniu hojności królewskiej, i rzadkich a wielkich zasług Stanisława Konarskiego ${ }^{42}$.

Przesłanie to tym bardziej znaczące, że wypowiedziane przez jezuitę, przedstawiciela konkurencyjnego na niwie edukacji zakonu. Odzwierciedlało zresztą nie jednostkowy pogląd, lecz przekonanie ogółu społeczeństwa. Najpewniej właśnie owa głęboko zakorzeniona świadomość - udokumentowana przecież i wierszem, i prozą - że wraz ze śmiercią tego skromnego zakonnika odchodzi postać niezwykle zasłużona wobec bliźnich i ojczyzny, wybitna, o którą z pewnością upomni się historia, sprawiła, iż zdecydowano się na oddzielenie serca od ciała, „aby się nie cały oddalał od nas - non totus recessit a nobis" ${ }^{43}$. Zachariasiewicz użył wprawdzie zacytowanych słów, mówiąc o medalu, ale w jeszcze większym stopniu mogłyby one odnosić się do cielesnej partykuły Konarskiego, zwłaszcza tak symbolicznie nacechowanej jak serce. Przecież w powszechnej opinii - wyrażonej przez Dymitra Michała Tadeusza Krajewskiego - było to serce idealne, które „dalekie od próżnych żądzy, o samą tylko dobijało się cnotę"44.

Na koniec pytanie trzecie: gdzie przez wiek cały - między rokiem 1773 a 1882 przechowywana była puszka z sercem Konarskiego?

Z cytowanego wspomnienia księdza Kasterskiego wynika, że serce Konarskiego znajdowało się w pijarskim kościele przy ulicy Długiej. Czy jednak było doń przeznaczone od samego początku? Raczej nie. Wybór miejsca złożenia serca dokonywany bywał - jeśli prześledzić poszczególne przypadki z XVIII wieku - w sposób dość jednoznaczny. Składano je - zgodnie z wolą zmarłego lub jego rodziny - w świątyni, której był fundatorem, w miejscu zatem, $\mathrm{z}$ jakim szczególnie emocjonalnie był związany. Nie inaczej musiało być w przypadku serca Konarskiego. Bez wątpienia więc po zamknięciu go w cynowej puszce trafiło

${ }^{42}$ G. Zachariasiewicz, Kazanie..., dz. cyt., s. 18.

43 G. Zachariasiewicz, Kazanie..., dz. cyt., s. 17.

${ }^{44}$ [D. M. T. Krajewski], Pochwała Stanisława Hieronima Konarskiego, dz. cyt., s. 90. 
ono nie do pijarskiego kościoła, lecz do kaplicy konwiktu Collegium Nobilium którego założycielem i pierwszym przełożonym był Konarski - znajdującego się nieopodal, przy ulicy Miodowej. Szkolne oratorium ulokowano na najwyższym piętrze pałacu, mającym charakter okazałej facjaty wznoszącej się ponad środkowym ryzalitem korpusu ${ }^{45}$. Nie zachowały się, niestety, żadne szersze deskrypcje tego wnętrza. Wychowanek konwiktu Prot Lelewel wspomniał jedynie, iż było wyłożone drewnem „ślicznie rżniętym”, znajdował się w nim „ołtarz misternej roboty” oraz „ławki, jak zwykle w kościołach, w dwa rzędy” " ${ }^{46}$. Zodnie z wezwaniem przybytku ów ołtarz mieścił obraz przedstawiający Dwunastoletniego Jezusa $w$ świątyni, a boczne ściany ozdobiły wizerunki bł. Józefa Kalasantego i św. Jana Nepomucena (namalował je w 1754 roku Szymon Czechowicz) ${ }^{47}$.

To przypuszczenie znajduje swego rodzaju potwierdzenie $\mathrm{w}$ emocjonalnie zabarwionej wypowiedzi Adolfa Malczewskiego, absolwenta niegdyś Collegium Nobilium w jego nowym wcieleniu jako Konwiktu Żoliborskiego. Tak relacjonował „Sztandar Polski” zdarzenie z uroczystości złożenia serca Konarskiego w Krakowie w 1882 roku:

Poruszył wszystkich i rozrzewnił weteran z wielkopolskiej ziemi, który powstawszy przemówił mniej więcej w te słowa: „Panowie! Jeżeli starzec stojący nad grobem, a zawsze wierny syn ojczyzny i żołnierz polski oraz wychowaniec księży pijarów na Żoliborzu, od których się nauczył kochać Boga i tę ojczyznę polską, służyć jej według sił, jeżeli świadectwo moje zasługuje na wiarę, to je dam prawdzie. Serce Konarskiego było znane każdemu wychowańcowi na Żoliborzu i wystarczyło do poprawy, jeżeli który z wychowańców zasłużył na naganę, gdy się ksiądz pijar do niego odezwał: «Serce Konarskiego patrzy na ciebie, co czynisz!»”. Łzy, które wytrysnęły z oczu szanownego weterana, nie dozwoliły mu dalej mówić. Stanowią one jednak - konkludował swą relację dziennikarz - jakby przyłożenie pieczęci na te dokumenty, które zgromadzeniu księży pijarów wraz z sercem do Krakowa ponadsyłano ${ }^{48}$.

45 Zob. R. Mączyński, Pijarski pałac Collegium Nobilium w Warszawie, Warszawa 1996, s. 34n; R. Mączyński, Zespoły architektoniczne..., dz. cyt., s. 229 n.

${ }_{46}$ Listy Joachima Lelewela. Oddział pierwszy: Listy do rodzeństwa pisane, t. 1, oprac. P. Lelewel, Poznań 1878, s. vi.

${ }_{47}$ Zob. R. Mączyński, Zespoły ołtarzowe warszawskiego kościoła pijarów, „Wiek Oświecenia” 14 (1998), s. 206n; R. Mączyński, Pijarski pałac..., dz. cyt., s. 35; R. Mączyński, Zespoły architektoniczne..., dz. cyt., s. 137n, 230.

${ }^{48}$ Uroczystość pochowania serca księdza Stanisława Konarskiego, „Sztandar Polski” 3 (1882) nr 24, s. 189 . 
Malczewskiego, w sędziwym już wieku, nierzadko pamięć zawodziła, więc niekiedy mocno koloryzował przeszłość, co ujawniła konfrontacja jego po latach snutych wspomnień z czasów młodości z twardą wymową dokumentów ${ }^{49}$. Trzeba zatem do jego słów podchodzić z ostrożnością. Ale to wspomnienie, niezmuszające do przypominania sobie zatartych w pamięci szczegółów, lecz mające charakter ogólny i zapewne głęboko - przez powtarzanie - utrwalony, wydaje się autentyczne. Koresponduje też niejako z domniemaniem wysuwanym w liście Jakuba Pika, który był głęboko przekonany, że „serce to poprzednio znajdowało się na Żoliborzu, to jest tam właśnie, gdzie Konarski był profesorem kolegiów pijarskich i skąd rozchodziło się światło jego potężnego umysłu" ${ }^{\circ}$. Błąd wiązania osoby Konarskiego z Konwiktem Żoliborskim sprostowano w broszurze utrwalającej dla potomnych przebieg uroczystości z $1882 \mathrm{roku}^{51}$. Nigdy też nie trafiło tam serce założyciela Collegium Nobilium. Dowodzą tego dokładne deskrypcje wszystkich budowli Konwiktu Żoliborskiego, spisane przez jego pomysłodawcę pijara Kajetana Kamieńskiego ${ }^{52}$.

Bo też relacja Adolfa Malczewskiego dotyczyć musiała jedynie porzekadła. Porzekadła wywodzącego się z tradycji ponad trzydziestoletniej obecności serca Konarskiego w oratorium konwiktu Collegium Nobilium przy ulicy Miodowej ${ }^{53}$. To właśnie z tamtejszej, wysoko usytuowanej szkolnej kaplicy musiało owo serce „patrzeć” na rozmaite dobre i złe uczynki konwiktorów, których sale służące do nauki, zabawy i mieszkania znajdowały się na niższych kondygnacjach pałacu. Dziejowe okoliczności sprawiły, że w roku 1807 obszerną tę rezydencję zarekwirowano czasowo dla potrzeb lazaretu. Pijarzy wraz z powierzoną ich opiece młodzieżą musieli przenieść się do sąsiadujących zabudowań Collegium Regium. Tam też poprzenoszono rozmaite konwiktowe sprzęty, „nagle, a zatem bez porządku i z wielką wszystkiego ruiną" ${ }^{54}$. Początkowo miano nadzieję powrotu do starej

49 Zob. R. Mączyński, Konwikt Żoliborski i pijarscy podopieczni w dobie powstania listopadowego, [w:] Z historii polskich pijarów. 35o-lecie Polskiej Prowincji Zakonu Pijarów, red. M. Ausz, Kraków 2013, s. 145n, 180n.

${ }^{50}$ Cyt. z listu Jakuba Pika do rektora Adama Słotwińskiego (z 15.01.1882): APPZP, rkps. sygn. 92, s. nlb.

${ }^{51}$ Analogiczne sformułowanie pojawia się jako komentarz do zacytowanego listu warszawskiego optyka, w obu wersjach relacji - i tej rękopiśmiennej: APPZP, rkps. sygn. 93, k. 2; i tej drukowanej: Uroczystość pochowania serca..., dz. cyt., s. 4.

${ }^{52}$ Zob. K. Kamieński, Opis historyczny Konwiktu Warszawskiego księży pijarów, oprac. R. Mączyński, „Analecta. Studia i Materiały z Dziejów Nauki” 3 (1994) nr 2, s. 7n.

${ }_{33}$ Dzieje pałacu Collegium Nobilium i jego strukturę opisuje: R. Mączyński, Pijarski pałac..., dz. cyt., s. 9n; R. Mączyński, Zespoły architektoniczne..., dz. cyt., s. 209 n.

${ }_{54}$ K. Kamieński, Opis historyczny ..., dz. cyt., s. 45. 
siedziby, lecz ostatecznie w 1811 roku sprzedano ją rządowi, postanawiając na stałe ulokować konwikt na parceli żoliborskiej (która wcześniej miała charakter letniej tylko rezydencji, służącej młodzieży do spędzenia wakacji) ${ }^{55}$. Jej zagospodarowywanie - pod rektorskimi rządami Kajetana Kamieńskiego - trwało jednak prawie dekadę. Dopiero w 1820 roku - po uprzednim przystosowaniu i rozbudowaniu domów mieszkalno-szkolnych - biskup warszawski Szczepan Hołowczyc poświęcił kaplicę konwiktorską, wolno stojącą, w formie klasycystycznej rotundy.

Najpewniej zatem około roku 1811, kiedy już było wiadomo, że konwikt nie powróci do dawnego pałacu Collegium Nobilium, postanowiono umieścić serce Stanisława Konarskiego w pijarskim kościele, co - jak wspomniano wcześniej odnotował Franciszek Kasterski. Uczyniona przezeń wzmianka jest jednak tak ogólnikowa, że nie pozwala dokładniej zlokalizować miejsca złożenia puszki $\mathrm{z}$ sercem. Wiadomo wprawdzie, że zakrystia była po stronie północnej kościoła, ale wcale nie komunikowała się $\mathrm{z}$,boczną nawą", lecz z ramieniem transep$\mathrm{tu}$, a i to nie bezpośrednio, lecz poprzez niewielki przejściowy aneks ${ }^{56}$. Puszka z sercem Konarskiego musiała znajdować się tam przez lat ponad 20, aż do roku 1834, kiedy na rozkaz władz rosyjskich - które zamierzały dotychczasowy kościół zakonny przebudować na prawosławny sobór Świętej Trójcy - pijarzy zmuszeni zostali opuścić własną siedzibę i przenieść się do przekazanych im w zamian zabudowań pojezuickich przy ulicy Świętojańskiej. Zabierając swój dobytek w nowe miejsce, wzięli również puszkę z sercem najsławniejszego polskiego pijara.

$\mathrm{W}$ druku towarzyszącym uroczystości z 1882 roku zanotowano też wypowiedź Adolfa Malczewskiego, który ponoć „,W roku 1844 słyszał z ust śp. księdza Franciszka Ksawerego Kurowskiego, pijara, swojego niegdyś profesora, że serce wyjęte $\mathrm{z}$ murów kościoła $\mathrm{w}$ roku $1834 \mathrm{w}$ miejscu bezpiecznym przechowane zostało" ${ }^{7}$. Nie wiadomo, dlaczego wtedy nie ulokowano go w objętej przez pijarów świątyni, podówczas zresztą staraniem rektora Jakuba Ciastowskiego wyremontowanej ${ }^{58}$. Może mając w świadomości popowstaniowe rekwizycje, wywożenie i niszczenie stołecznych zbiorów artystycznych i historycznych, choćby tych należących do Warszawskiego Towarzystwa Przyjaciół Nauk, obawiano się zbytniego eksponowania osoby Konarskiego, uznanego przez władze zaborcze

55 Zob. R. Mączyński, Żoliborski konwikt pijarów, „Analecta. Studia i Materiały z Dziejów Nauki” 3 (1994) nr 1, s. 7n.

${ }^{56}$ Dzieje warszawskiego kościoła pijarów i jego strukturę omawia: R. Mączyński, Zespoły architektoniczne..., dz. cyt., s. 94n.

57 Analogiczne sformułowanie pojawia się w obu wersjach relacji - i tej rękopiśmiennej: APPZP, rkps. sygn. 93, k. 4; i tej drukowanej: Uroczystość pochowania serca..., dz. cyt., s. 6.

${ }_{58}$ Zob. R. Mączyński, Wina i kara..., dz. cyt. 
za inicjatora patriotycznego wychowania wpajanego młodzieży przez pijarską edukację $^{59}$. A może po prostu nie starczyło funduszy i energii, bo cios, jakim dla zakonników stało się zabranie im przez półtora stulecia gromadzonego majątku, podcinające ekonomiczny byt kolegium, spadł na nich jednocześnie z innym - jeszcze dotkliwszym - jakim był wydany przez władze zaborcze zakaz dalszego prowadzenia szkół, gdyż to w ogóle podważało sens działalności pijarów, zobowiązanych ślubowaniem do pracy nauczycielskiej. Przecież właśnie dlatego pieczołowicie niegdyś gromadzone przez nich zbiory - czy to ksiąg, czy to narzędzi fizycznych - trwały w stanie nieuporządkowanym przez trzy dekady, aż do kasaty ${ }^{60}$.

Z obecnej perspektywy najważniejsze zdaje się wszakże, że niezależnie od wszystkich niesprzyjających dziejowych zdarzeń, jakie dotknęły zakon pijarów, w krakowskim ich kościele istnieje, ocalona od unicestwienia, ta niewielka cielesna partykuła wielkiego męża Rzeczypospolitej xvıII wieku (il. 17) ${ }^{61}$.

\section{Bibliografia}

\section{Źródła}

Albertrandi J. C., Opisanie medalu Stanisława Konarskiego z wykładem historyczno-krytycznym czynów i dzieł tego męża, „Dziennik Wileński” 6 (1817), s. 633.

Archiwum Polskiej Prowincji Zakonu Pijarów w Krakowie (dalej: APPZP), rkps sygn.

AP V-1/1 (dawna sygn. S-1): Matricula Provinciae Polonae Scholarum Piarum 1742-1867. APPZP, rkps sygn. Col. Cracov. 92: Dokumenty odnalezienia i pochowania w Krakowie serca ks. Stanisława Konarskiego.

APPZP, rkps sygn. Col. Cracov. 93: Uroczystość pochowania serca śp. ks. Stanisława Konarskiego $w$ kościele pijarów krakowskich.

APPZP, rkps sygn. Col. Cracov. 207: Krótka historia założenia kolegium krakowskiego

i inwentarz kościoła Przemienienia Pańskiego. APPZP, rkps sygn. Col. Lov. 3: Liber suffragiorum Loviciensis 1657-1781.

59 Szeroko na temat owego rekwirowania zbiorów artystycznych, historycznych i naukowych: Z. Strzyżewska, Konfiskaty warszawskich zbiorów publicznych po powstaniu listopadowym. Biblioteka Uniwersytetu Warszawskiego i Warszawskie Towarzystwo Przyjaciół Nauk. Materiały i dokumenty $z$ archiwów rosyjskich, Warszawa 2000, passim.

${ }^{60}$ Zob. R. Mączyński, Warszawskie biblioteki..., dz. cyt., s. 128n.

${ }^{61}$ Za umożliwienie wykonania fotografii dokumentujących obecny stan zachowania szkatulki z puszką kryjącą serce winien jestem wdzięczność ojcu Mieczysławowi Rolce, rektorowi kolegium krakowskiego Szkół Pobożnych. 
APPZP, rkps sygn. RAC 10: Dokumenty dotyczące pijarów warszawskich, dok. 4.

[Bielski S.], Vita et scripta quorundam e Congregatione Cler[icorum] Reg[ularium] Scholarum Piarum in Provincia Polona professorum, qui operibus editis patriae et ecclesiae proficuis nomen suum memorabile fecerunt, Varsaviae 1812.

Jakubowski W., Życie Stanisława Konarskiego, S[cholarum] P[iarum], krótko zebrane..., [w:] S. Konarski, Wiersze wszystkie z łacińskich na polskie przełożone, Warszawa 1778, s. nlb.

Historia Domus Varsaviensis Scholarum Piarum, oprac. L. Chmaj, Wrocław 1959.

[Krajewski D. M. T.], Pochwała Stanisława Hieronima Konarskiego, Warszawa 1783.

Listy Joachima Lelewela. Oddział pierwszy: Listy do rodzeństwa pisane, t. 1, oprac. P. Lelewel, Poznań 1878.

Protokół pomieszczenia serca Stanisława Konarskiego $w$ kolegium ks.ks. pijarów w Krakowie, „Tygodnik Ilustrowany” 13 (1882) nr 319, s. 79.

Relacja o depozycji serca Jaśnie Oświeconego Księcia Jegomości Teodora Lubomirskiego, wojewody krakowskiego, [...] przy solennych egzekwiach $w$ kościele warszawskim $x x$. Scholarum Piarum, [Warszawa 1745].

Relacja z pogrzebu serca [...] Jaśnie Wielmożnego Jegomości Pana Jana Tarła, wojewody sandomierskiego, $w$ kościele warszawskim xx. Scholarum Piarum, [Warszawa 1750].

Uroczystość pochowania serca księdza Stanisława Konarskiego, „Sztandar Polski” 3 (1882) nr 24, s. 189.

Uroczystość pochowania serca śp. x. Stanisława Konarskiego pijara w kościele xx. pijarów krakowskich $w$ dniu 13 lutego 1882 roku, Kraków 1882.

„Wiadomości Warszawskie” 9 (1773) nr 62 (z 4 viıI, suplement), s. nlb.

Wiązkiewicz P., Skarb nowy dotąd niewiadomych łask i nieznanych dobrodziejstw Najświętszego Serca Jezusowego w roku 1705 dnia 30 maja $z$ wielkimi i osobliwymi odpustami przez [...] Klemensa XI nadanymi [...] w kościele warszawskim xx. Scholarum Piarum ... wiernym otworzony, Warszawa 1734.

Zachariasiewicz G., Kazanie [...] miane na pogrzebie x. Stanisława Konarskiego, Scholarum Piarum, dnia 5 sierpnia roku 1773, [Warszawa 1773].

\section{Opracowania}

Badach A., Pogrzeby serc na ziemiach wschodnich Rzeczypospolitej w XVIII wieku. Wprowadzenie do zagadnienia i postulaty badawcze, [w:] Sztuka ziem wschodnich Rzeczypospolitej XVI-XVIII wieku, red. J. Lileyko, Lublin 2000, s. 639n.

Badach A., Rzeźba. Katalog zbiorów. Zamek Królewski w Warszawie. Fundacja Zbiorów im. Ciechanowieckich. Fundacja Teresy Sahakian, Warszawa 2011.

Bogdziewicz H., O ks. Stanisławie Konarskim i innych pijarach w poezji, Kraków 2000. Buba J., Odważył się być mądrym, oprac. L. Mazan, „Przekrój” 39 (1983) nr 1973, s. 14. 
Buba J., Początki czci publicznej Serca Bożego, [w:] Pijarzy w kulturze dawnej Polski. Ludzie i zagadnienia, Kraków 1982, s. 48n.

Chachulski T., Stanisław Konarski, Warszawa 2000.

Chromecki T., Krótki rys dziejów zgromadzenia Szkół Pobożnych, czyli oo. pijarów, Kraków 1880.

Culto a Corazón de Jesús, [w:] Diccionario enciclopedico escolapio, t. 5: Escolapios en Polonia y Lituania, coord. L. M. Bandrés Rey, Salamanca 1985, s. 78n.

Czuma M., Mazan L. (współpraca Rożek M.), Poczet serc polskich, Kraków 2005.

Czyż A. S., O pochówkach serc Michała Korybuta Wiśniowieckiego i Klary Izabelli de Mailly-Lascaris Pacowej oraz nekropoli Paców w Pożajściu, „Biuletyn Historii Sztuki” 75 (2013) nr 4, s. $671 \mathrm{n}$.

Derwojed J., Błotnicki Tadeusz, [w:] Słownik artystów polskich i obcych w Polsce działających. Rzeźbiarze, malarze, graficy, t. 1, Wrocław 1971, s. 186n.

Drążek C., Rozwój kultu Serca Jezusa w Polsce, [w:] Bóg bliski. Historia i teologia kultu Najświętszego Serca Jezusa, Kraków 1983, s. 11n.

Gajewski J., Sztuka w prymasowskim Łowiczu, [w:] Łowicz, dzieje miasta, red. R. Kołodziejczyk, Warszawa 1986, s. 556n.

Goliński Z., Stanisław Konarski (17oo-1773), [w:] Pisarze polskiego oświecenia, t. 1, red. T. Kostkiewiczowa, Z. Goliński, Warszawa 1992, s. 13n.

Kamieński K., Opis historyczny Konwiktu Warszawskiego księży pijarów, oprac. R. Mączyński, „Analecta. Studia i Materiały z Dziejów Nauki” 3 (1994) nr 2, s. 7 n.

Konarski S., Pik Jakub, [w:] Polski słownik biograficzny, t. 26, Wrocław 1981, s. 219.

Konopczyński W., Stanisław Konarski, Warszawa 1926.

Lenartowicz T., Złote serce. Wiersz ku czci ks. pijara Stanisława Hieronima Konarskiego, Kraków 1882.

Mączyński R., Konterfekty zwielokrotnione. Rozważania nad wizerunkami pijara Stanisława Konarskiego, Toruń 2014. Mączyński R., Medale zasłużonych pijarów, „Rocznik Warszawski” 20 (1988), s. 190 .

Mączyński R., Konwikt Żoliborski i pijarscy podopieczni $w$ dobie powstania listopadowego, [w:] Z historii polskich pijarów. 35o-lecie Polskiej Prowincji Zakonu Pijarów, red. M. Ausz, Kraków 2013, s. 145n.

Mączyński R., Pijarski pałac Collegium Nobilium w Warszawie, Warszawa 1996.

Mączyński R., Warszawskie biblioteki księży pijarów, „Rocznik Historii Sztuki” 23 (1998), s. 130.

Mączyński R., Wina i kara. Powstaniowe i popowstaniowe losy warszawskich pijarów (1830-1866), [w:] Losy klasztorów i zbiorów poklasztornych w okresie represji po upadku powstania listopadowego $w 1831$ roku, red. M. Derwich [publikacja pokonferencyjna z 12-15.07.2012 w Rytwianach, w druku]. 
Mączyński R., Zespoły architektoniczne Collegium Regium i Collegium Nobilium warszawskich pijarów 1642-1834, Warszawa 2010.

Mączyński R., Zespoły ołtarzowe warszawskiego kościoła pijarów, „Wiek Oświecenia” 14 (1998), s. 206n.

Mączyński R., Żoliborski konwikt pijarów, „Analecta. Studia i Materiały z Dziejów Nauki” 3 (1994) nr 1, s. 7 n.

Mikocka-Rachubowa K., André Le Brun, „pierwszy rzeźbiarz” króla Stanisława Augusta, t. 2, Warszawa 2010.

Nieciecki J., Materiały do pomnika serca Jana Klemensa Branickiego w Białymstoku, [w:] Studia nad sztuka renesansu $i$ baroku, t. 8: Fundator $i$ dzieło $w$ sztuce nowożytnej, cz. 3, red. J. Lileyko, I. Rolska-Boruch, Lublin 2007, s. 169 n.

Nowak-Dłużewski J., Stanisław Konarski, Warszawa 1951.

Pitala A., Kolegium pijarów w Krakowie, Kraków 1994.

Rose W. J., Stanislas Konarski. Reformer of Education in XVIIIth century Poland, London 1929.

Słowiński L., Odważni mądrością. O reformatorach edukacji i nauki polskiej $w$ dobie oświecenia, Poznań 1988.

Stępień R., Ks. Stanisław Konarski w opinii niektórych współczesnych mu Polaków, [w:] Studia $z$ dziejów oświaty XVIII-XX wieku, red. M. Chamcówna, Wrocław 1993.

Strzyżewska Z., Konfiskaty warszawskich zbiorów publicznych po powstaniu listopadowym. Biblioteka Uniwersytetu Warszawskiego i Warszawskie Towarzystwo Przyjaciół Nauk. Materiały i dokumenty z archiwów rosyjskich, Warszawa 2000.

Suchodolski B., Stanisław Konarski, [w:] Z dziejów polskiej myśli filozoficznej i społecznej, t. 2: Wiek XVIII - oświecenie, red. B. Suchodolski, Warszawa 1956, s. 72n.

Świeboda J., Pijarzy w Rzeszowie w XVII-XVIII wieku, Kraków 2012.

Wiadomości literackie, artystyczne i naukowe, „Bluszcz” 17 (1882) t. 28, nr 6, s. 48, nr 8; s. 63.

Wójcicki K. W., Cmentarz Powązowski pod Warszawa, t. 2, Warszawa 1856.

X. S. Ch. [Chodyński S.], Pogrzeb, [w:] Encyklopedia kościelna, t. 20, red. M. Nowodworski, Warszawa 1894, s. 140.

Żak S., Ksiądz Stanisław Konarski (pisarz - pedagog - polityk), Kielce 2001. 


\section{Abstrakt}

Artykuł zwraca uwagę na interesujący zabytek sprzed 130 lat, znajdujący się w krakowskim kościele pijarów - plastyczną oprawę miejsca złożenia serca Stanisława Konarskiego (1700-1773), zakonnika Szkół Pobożnych z XVIII stulecia, a przy tym wydawcy zbioru praw krajowych Volumina legum, odważnego publicysty domagającego się wzmocnienia władzy królewskiej i zwalczającego liberum veto, reformatora szkolnictwa i założyciela słynącej z nowoczesności uczelni Collegium Nobilium. Kreśli także okoliczności przeniesienia w 1882 roku tej „relikwii” z Warszawy do Krakowa oraz opisuje uroczystość wprowadzenia jej 13 lutego do zakonnej świątyni pod wezwaniem Przemienienia Pańskiego. Podejmuje również trzy istotne kwestie badawcze.

Pierwsza kwestia, która też wielce zajmowała współczesnych - a szczególnie rektora kolegium krakowskiego Adama Słotwińskiego - to problem autentyczności owej pamiątki, która ujawniona została po ponad stu latach od pogrzebu zasłużonego pijara, w prywatnym posiadaniu warszawskiego optyka Jakuba Pika. Zwłaszcza że brakuje jakichkolwiek bezpośrednich świadectw z 1773 roku mówiących o odłączeniu po śmierci Stanisława Konarskiego jego serca od ciała. Jednak zgromadzone przesłanki pozwalają przyjąć z prawdopodobieństwem graniczącym z pewnością, iż jest to autentyczna - i zarazem jedyna po dziś dzień zachowana - cielesna partykuła sławnego zakonnika.

Druga kwestia, całkowicie pomijana w ówczesnej refleksji, to przyczyna odłączenia serca od ciała. Ten aspekt rozważań kazał zwrócić uwagę na niezwykle rozpowszechnioną w Rzeczypospolitej - najpierw pośród rodzin monarszych, później także magnaterii i szlachty - nowożytną tradycję osobnych pochówków serc, zazwyczaj składanych w ufundowanej przez zmarłego świątyni. Wskazano, że szczególnie wiele serc oddzielonych od ciał spoczęło w kościołach pijarskich (Rzeszów, Warszawa czy Łowicz). Nie był to jednak obyczaj stosowany wobec zakonników. Casus serca Stanisława Konarskiego dowodzi, że w opozycji wagi wiekopomnych zasług do ślubów zakonnej pokory - zwyciężyły zasługi.

Trzecia kwestia, której nie potrafili rozwikłać współcześni, dotyczyła miejsca pierwotnego przeznaczenia puszki z sercem Konarskiego. Konfrontacja skromnych wzmianek z sytuacją warszawskich pijarów w pierwszej połowie XIX wieku pozwoliła ujawnić drogę, jaką ona przebyła. W 1773 roku umieszczono ją w kaplicy konwiktorskiej w pałacu Collegium Nobilium, następnie około 1811 roku została przeniesiona do pijarskiego kościoła przy ulicy Długiej, w roku 1834 zakonnikom zarekwirowano ich świątynię, więc cielesna partykuła Stanisława Konarskiego trafiła do gmachu objętego przez nich kolegium przy ulicy Jezuickiej. Tam znajdowała się do 1866 roku, a po kasacie zakonu znalazła się w rękach Jakuba Pika.

Ten starannie ją przechował i ofiarował do krakowskiego kościoła pijarów w Krakowie, gdzie w 1882 roku umieszczono ją w niszy w ścianie prezbiterium. Plastyczną oprawę tego miejsca zaprojektował Tadeusz Łepkowski, ówczesny konserwator zabytków. Zaś popiersie portretowe Stanisława Konarskiego wykonał krakowski rzeźbiarz Tadeusz 
Błotnicki. Rysy twarzy odwzorował na podstawie konterfektu z czasów Stanisława Augusta - rzeźby André Le Bruna, należącej do pocztu mężów szczególnie dla Rzeczypospolitej zasłużonych, jaki ozdobił otwartą w 1786 roku Salę Rycerską na Zamku Królewskim w Warszawie.

\section{Słowa kluczowe}

Stanisław Konarski, serce, pochówek, epitafium, upamiętnienie, pijarzy, Kraków

\section{Abstract \\ The memorable service and monastic humility - the history of Stanisław Konarski's heart}

The article concentrates on an interesting 130-year-old artefact located in the Krakow church of Piarists - the decoration of the place where Stanisław Konarski’s (1700-1773) heart was buried. Konarski was a monk of the Pious Schools in the $18^{\text {th }}$ century, as well as publisher of a collection of national laws Volumina legum, a bold commentator calling for strengthening royal power and abolishing liberum veto, reformer of the educational system and founder of the renowned, modern Collegium Nobilium. The circumstances of the discovery and relocation of the relic in 1882 from Warsaw to Krakow and the ceremony of its introduction to the monastic Church of the Transfiguration of Jesus on February 13 are also outlined. Three significant research issues are also discussed.

The first one is the problem of the authenticity of the artefact, which was discovered more than a hundred years after Konarski's death in the possession of a Warsaw optician Jakub Pik. It was then that the question started occupying the minds of researchers, including the rector of the Krakow college Adam Słotwiński. The question is made more relevant by the lack of any direct evidence from 1773 about the removal of Stanisław Konarski's heart from his body after his death. The information gathered so far allow us to assume, with probability bordering on certainty, that it is authentic and the only surviving part of this famous monk's body.

Another question, totally absent from past reflections on the subject, is the reason why the heart was removed. This particular aspect turns our attention at a strikingly 
popular early-modern Polish tradition - first in royal families, later also among magnates and nobility - of burying hearts separately, usually by entombing them in a church founded by the deceased. It was found that a considerable number of hearts removed from bodies had been inhumed in Piarist churches (Rzeszów, Warsaw or Łowicz). This tradition, however, did not normally apply to monks. The case of Stanisław Konarski's heart proves that in the juxtaposition of great merit and monastic vows of humility the merit prevailed.

A third question, which contemporaneous researchers could not answer, is the original destination of the box with Konarski's heart. A confrontation of scant mentions with the situation of Warsaw Piarists in the first half of the $19^{\text {th }}$ century allows us to retrace its route. In 1773 it was placed in the monastic school chapel at Collegium Nobilium, then in 1811 it was relocated to the Piarist church in Długa street; in 1834 the order was deprived of the church, so Konarski's heart was brought to their college in Jezuicka street. It was held there until 1866, and after the dissolution of the order it was in the possession of Jakub Pik.

Pik carefully stored the relic and donated it to the Piarist church in Krakow, where in $\mathbf{1 8 8 2}$ it was placed in an alcove in the presbytery. The decoration of the place was designed by Tadeusz Łepkowski, the then restorer. Stanisław Konarski's bust was sculpted by Tadeusz Błotnicki from Krakow. Facial features were reproduced on the basis of an image from the times of Stanisław August - a sculpture by André Le Brun, displayed in a gallery of people of particular merit to the Republic of Poland opened in the Knights' Hall at the Royal Castle in Warsaw in 1786.

\section{Keywords}

Stanisław Konarski, heart, burial, epitaph, commemoration, Piarists, Krakow 


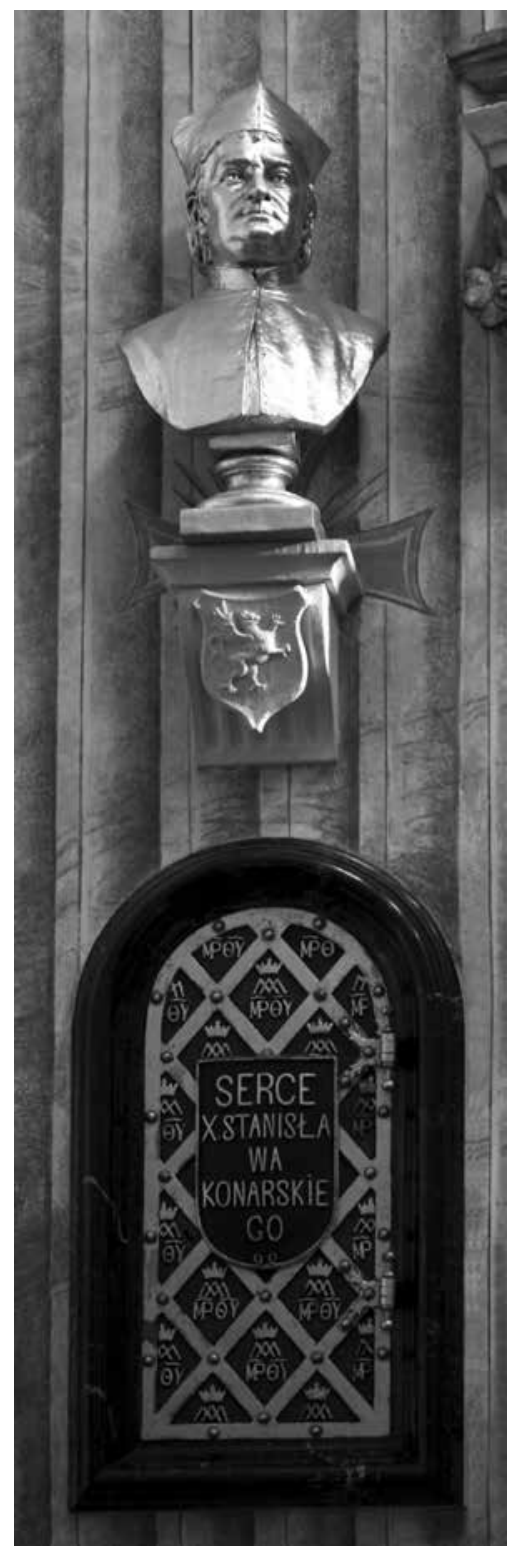

1. Kraków, kościół pijarów. Plastyczna oprawa miejsca złożenia puszki z sercem Stanisława Konarskiego, wykonana według projektu Józefa Łepkowskiego (1882). Fot. Ryszard Mączyński 


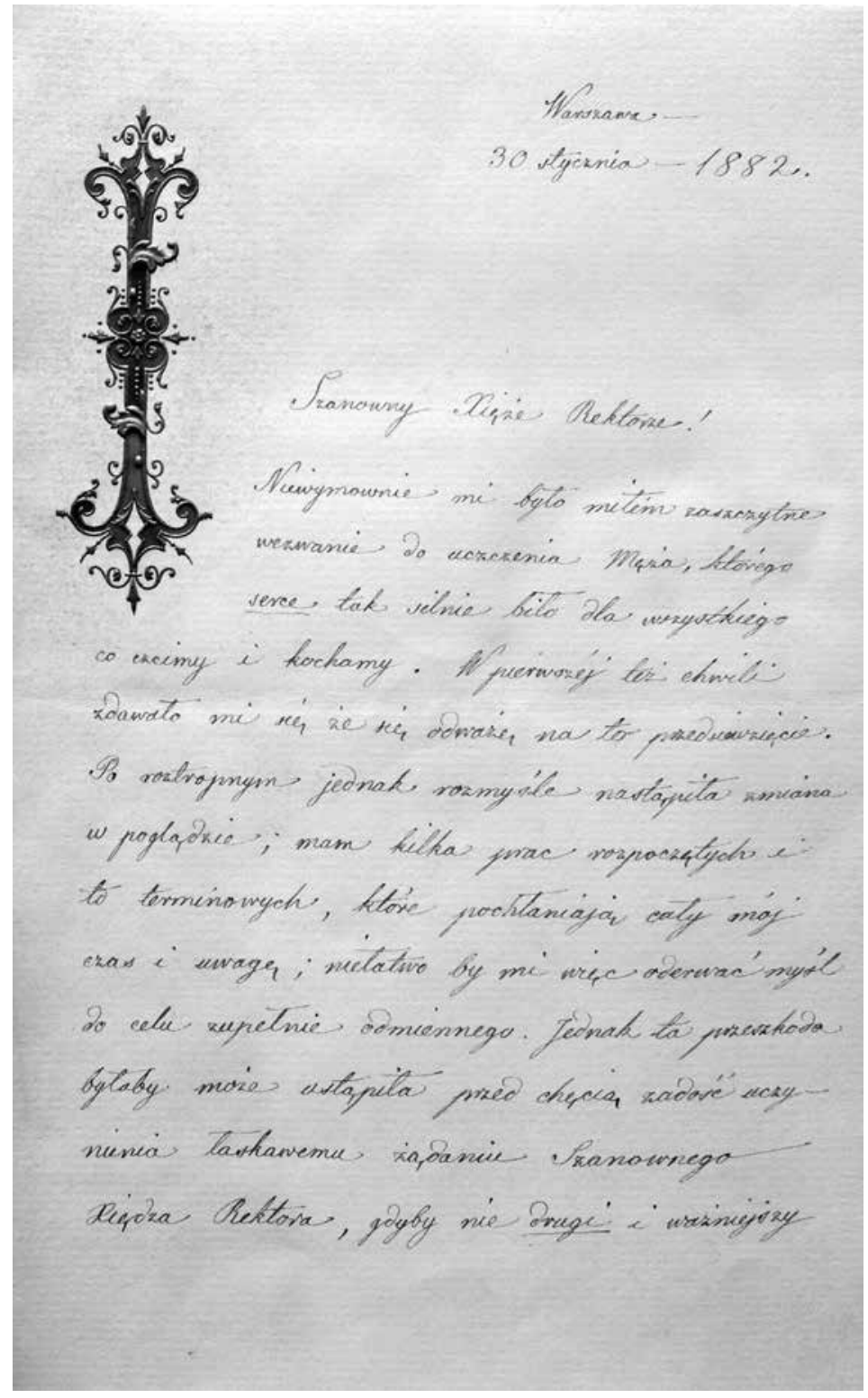

2. List Jadwigi Łuszczewskiej (Deotymy) do rektora Adama Słotwińskiego z 30 stycznia 1882 roku. W zbiorach Archiwum Polskiej Prowincji Zakonu Pijarów w Krakowie. Fot. Ryszard Mączyński 


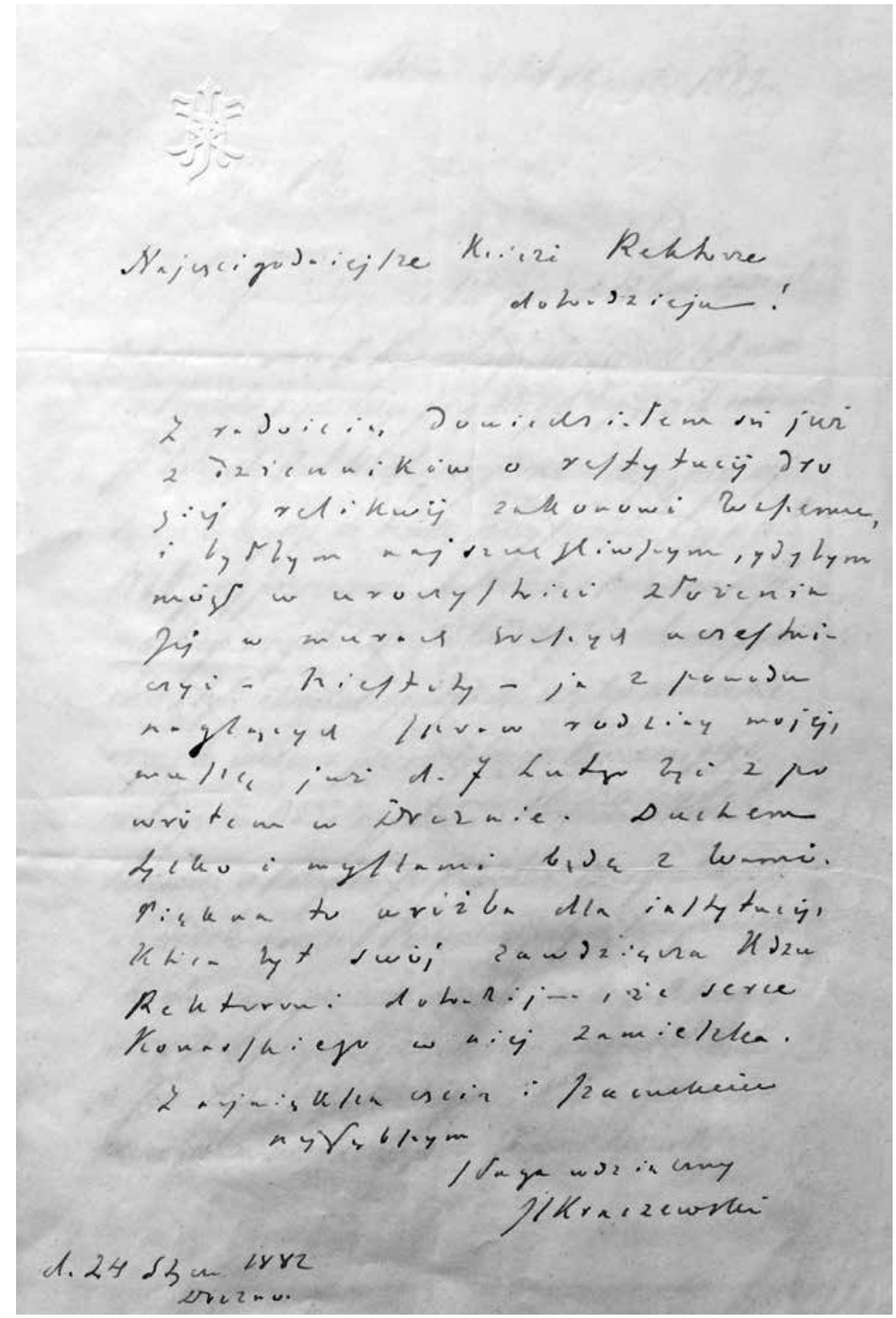

3. List Józefa Ignacego Kraszewskiego do rektora Adama Słotwińskiego z 24 stycznia 1882 roku. W zbiorach Archiwum Polskiej Prowincji Zakonu Pijarów w Krakowie. Fot. Ryszard Mączyński 
$x=$ Stanistama Sonarskiego

$$
\begin{aligned}
& \text { Pari sunt parented, cari amici, cari } \\
& \text { penitiares, ded ominum charilater amor } \\
& \text { fatrid smperat. Oicero }
\end{aligned}
$$

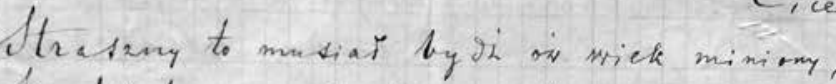
Shateristrem moingly, swarda pijang,

Riedy jedneme leimse na miliany,

QDwaoi melica nagrots pragenamo.

- Hedal mybily 2 tym itrasemper napivem

A live debory Pirnatokiage trave

Ida is nie detem e imutrym Eypryeem

C. nad mogity psthmanemi stawa

veili to pranda co ten tas ayreke.

L imiersis jednego osi An woyitkil, creka

10.

jana satach wrescery o molnois.

Jabli w gajand dobyerajer ktatmi,

Kiedy ma prlach wiator ponura kójis

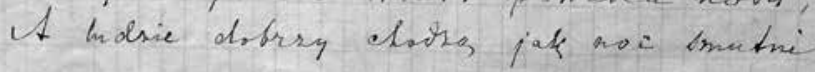

Oboys najardios prospommienia Sariesa,

praed ros rucongh miast is gerbig 2 glivecre

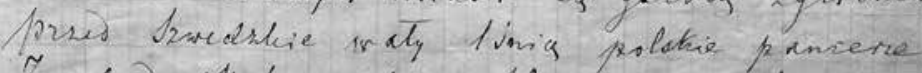

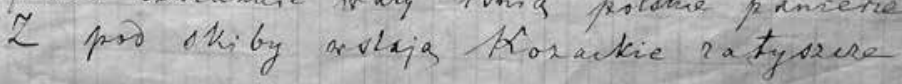

4. Autograf poematu Złote serce Teofila Lenartowicza (pod pierwotnym jeszcze, później zmienionym tytułem) z 28 stycznia 1882 roku. W zbiorach Archiwum Polskiej Prowincji Zakonu Pijarów w Krakowie.

Fot. Ryszard Mączyński 


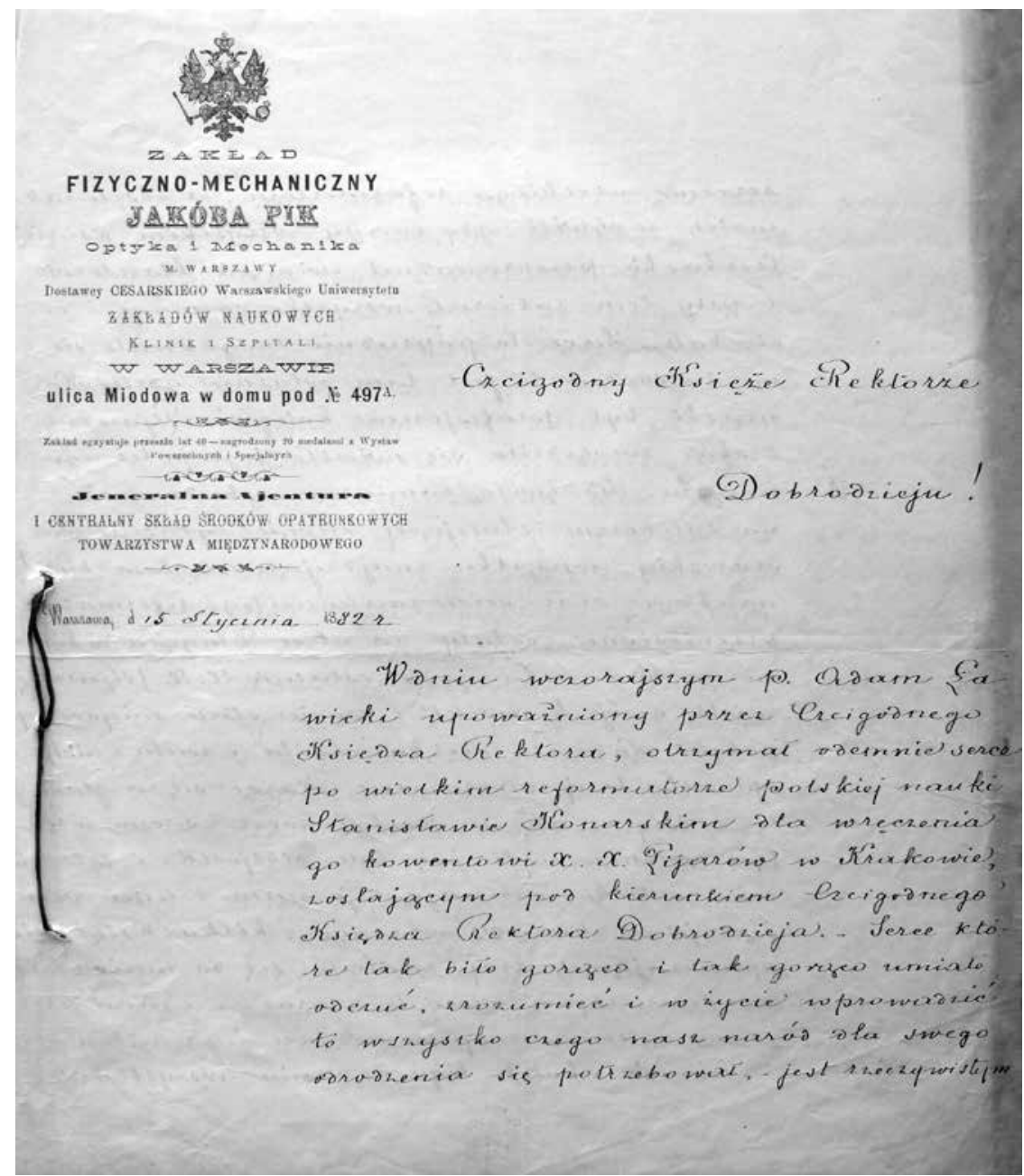

5. List Jakuba Pika do rektora Adama Słotwińskiego z 15 stycznia 1882 roku. W zbiorach Archiwum Polskiej Prowincji Zakonu Pijarów w Krakowie.

Fot. Ryszard Mączyński 


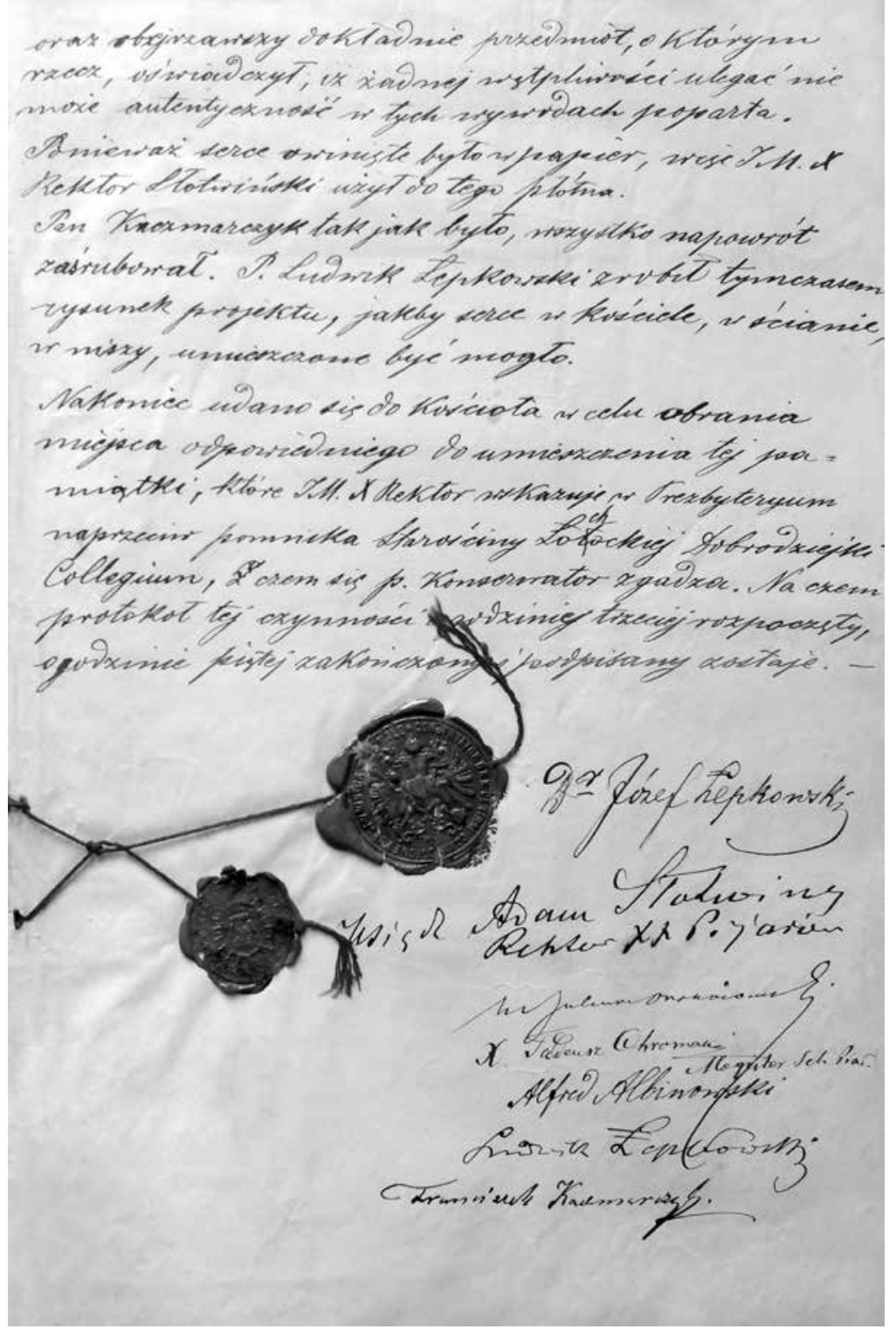

6. Protokół oględzin puszki z sercem Konarskiego z 18 stycznia 1882 roku ostatnia strona z podpisami członków komisji. W zbiorach Archiwum Polskiej Prowincji Zakonu Pijarów w Krakowie. Fot. Ryszard Mączyński 


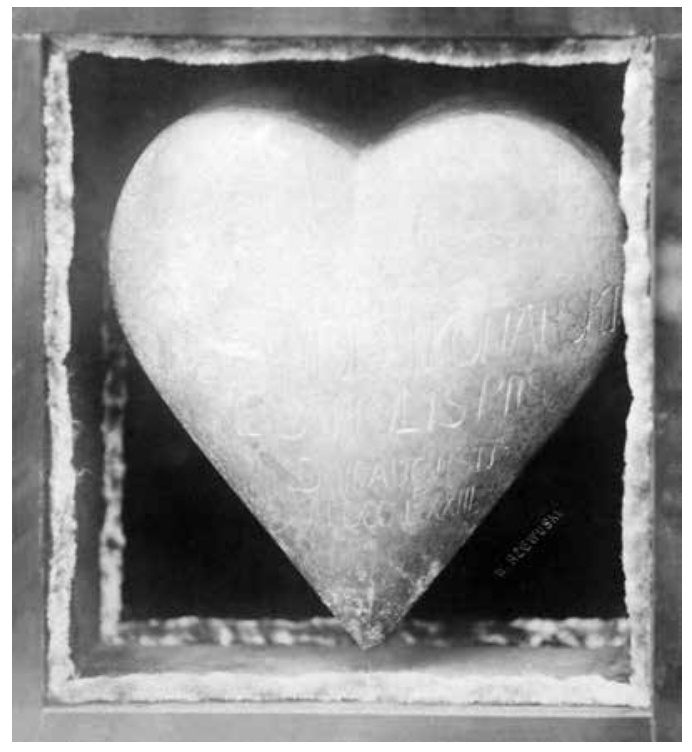

7. Puszka z sercem Konarskiego uwieczniona na fotografii wykonanej przez Walerego Rzewuskiego (1882). W zbiorach Archiwum Polskiej Prowincji Zakonu Pijarów w Krakowie. Fot. Ryszard Mączyński

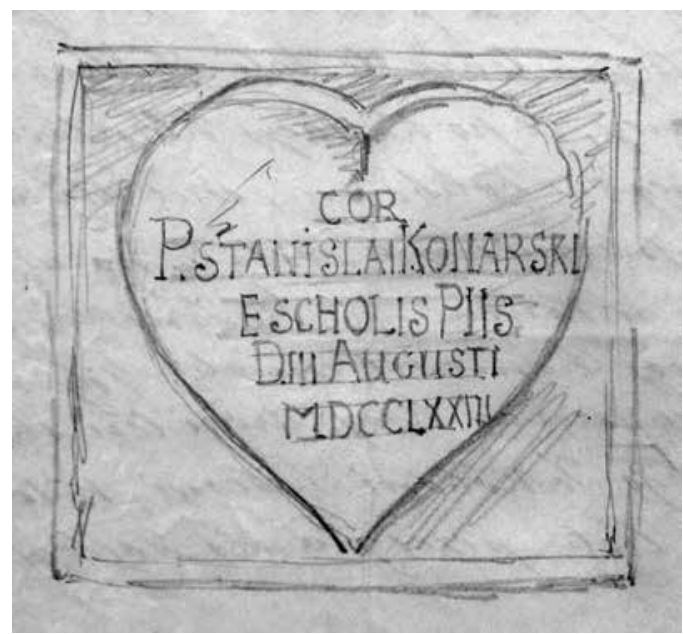

8. Szkicowy rysunek puszki z sercem Konarskiego zawarty w protokóle oględzin z 18 stycznia 1882 roku. W zbiorach Archiwum Polskiej Prowincji Zakonu Pijarów w Krakowie. Fot. Ryszard Mączyński 


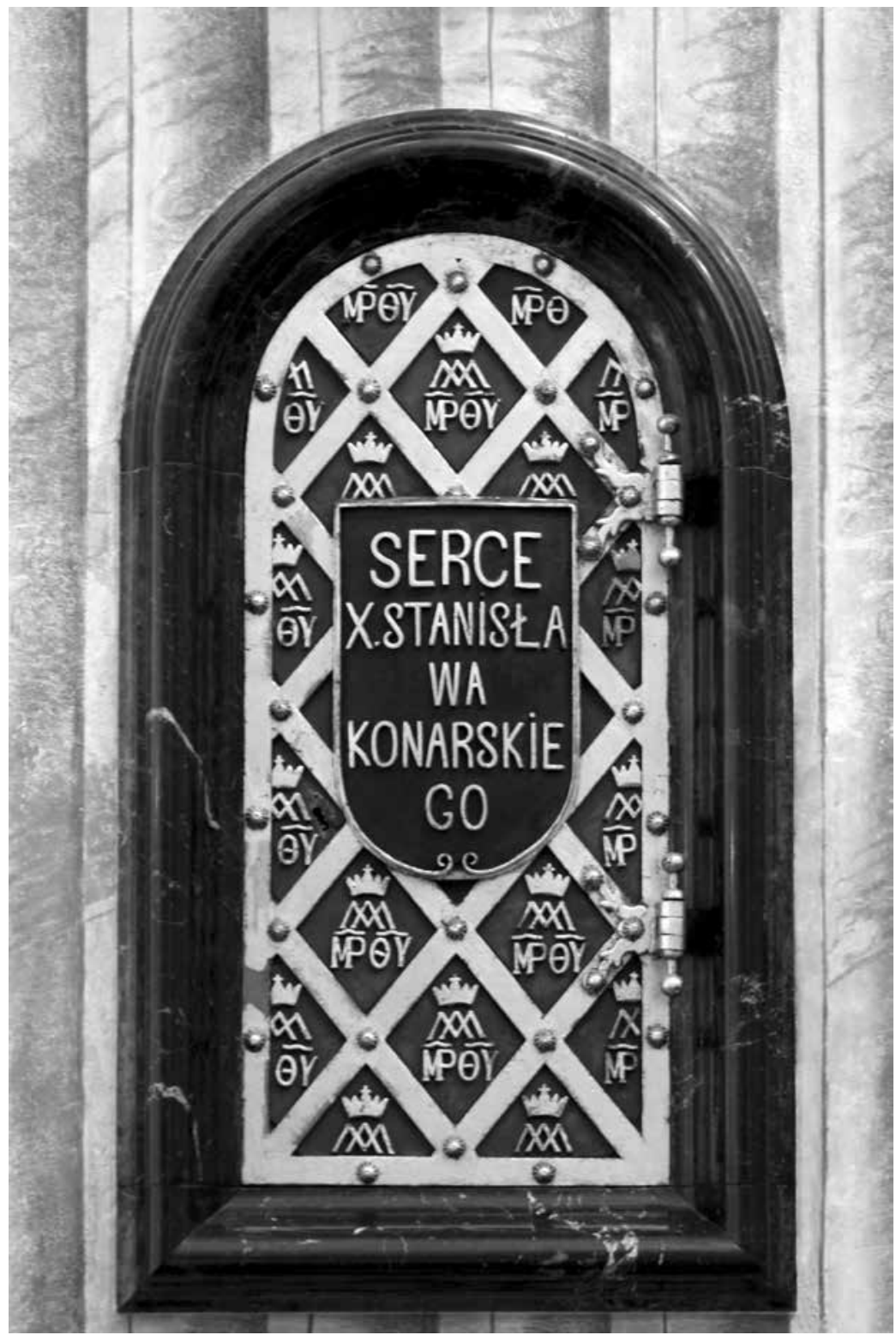

9. Kraków, kościół pijarów.

Oprawa i zamknięcie niszy, w której złożono puszkę z sercem Konarskiego (1882). Fot. Ryszard Mączyński 

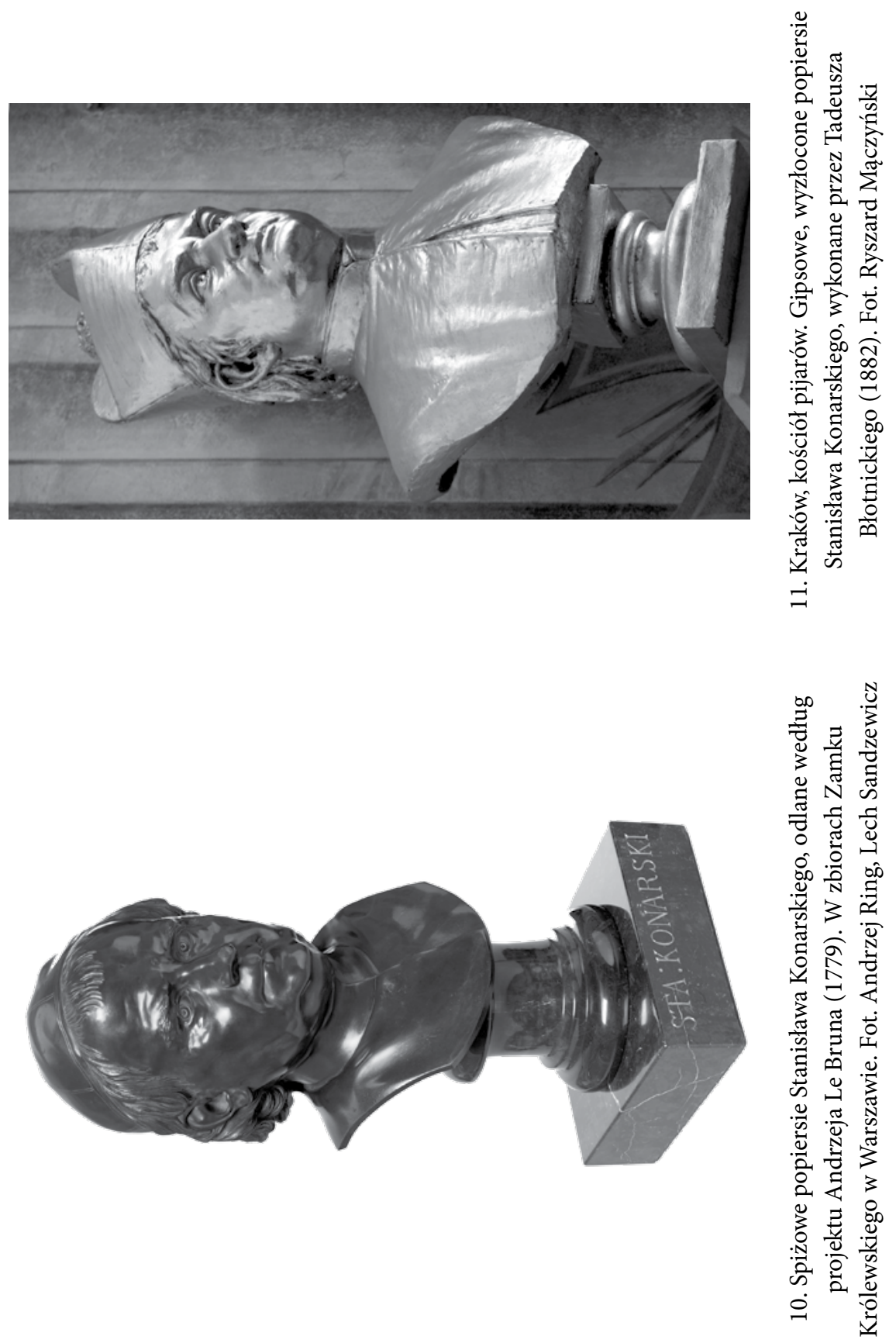


\section{WIECZOREK \\ MUZYKALNO-DEKLAMACYJNY}

NA CZESC S. P.

\section{STANISEAWA KONARSKIEGO}

\section{PIJARA,}

WIELKIEGO REFORMATORA NAUK W POLSCE

urządzony przez

\section{konwiktorów Zakładn wychowawczo-nankowego XX. Pijarów}

\section{dnia 13 Lutego $1882 \mathrm{r}$.}

w uroczystosé nlokowania serea \&. p. Stanisława Konarskiego w kościele XX. Pijarów w Krakowie.

\section{PR OGRA M.}

1). Odczyt: „O wpływie reform Konarskiego, odnoszących się do wychowania".

2). Beriot. "Fantazya* (fortepian i skrzypce).

3). Dek la macya. "Kradzione".

4). D a n cl. „Resignation “ (fortepian i skrzypce).

5). Poemat Te ofila Lenartowi c za na cześé serca St. Konarskiego (odczyta jeden z Członków Czytelni Akademickiéj).

6). O b n is k i. "Kołysanka" (fortepian i skrzypce).

7). Dekl a macya. "Ojciec zadżumionych“.

8). Wieniawski. "Kujawiak".

9). Przemówien ie Rektora XX. Pijarów.

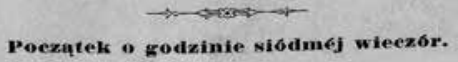

12. Program wieczorku muzykalno-deklamacyjnego ku czci Stanisława Konarskiego w dniu 13 lutego 1882 roku. W zbiorach Archiwum Polskiej Prowincji Zakonu Pijarów w Krakowie. Fot. Ryszard Mączyński 


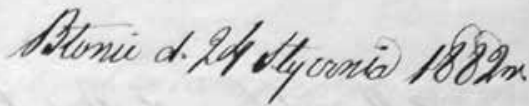

Ath. Ifter:

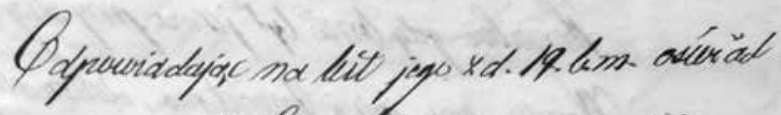

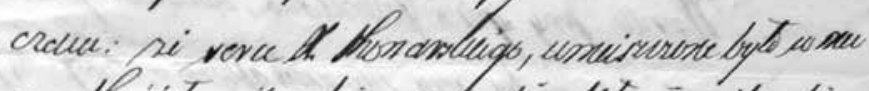

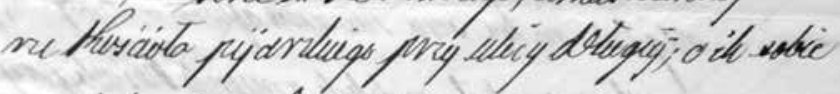

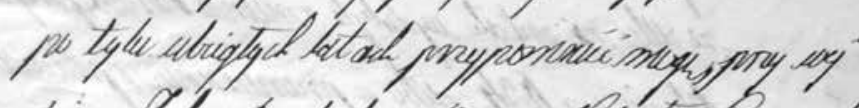

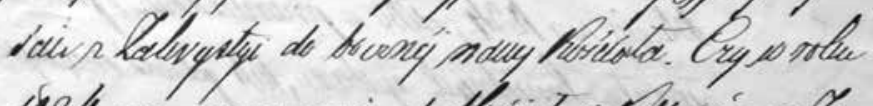

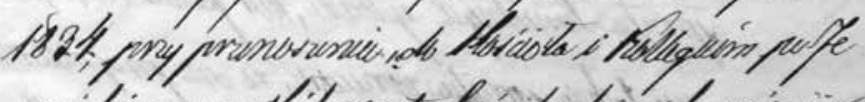

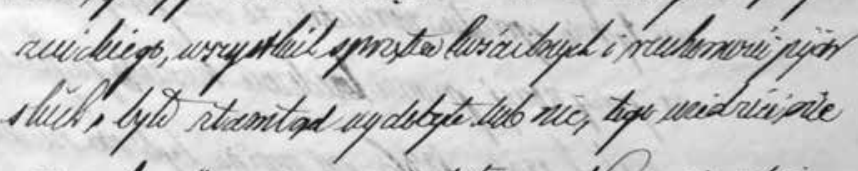

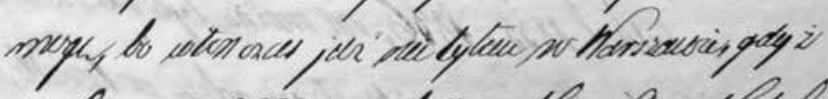

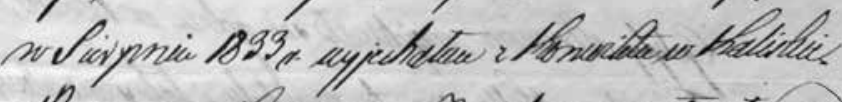

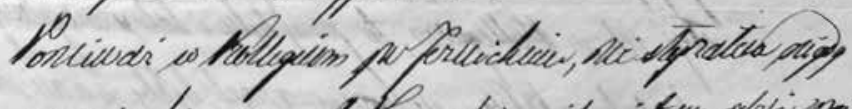

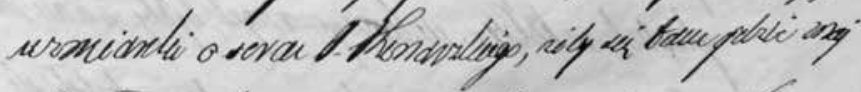

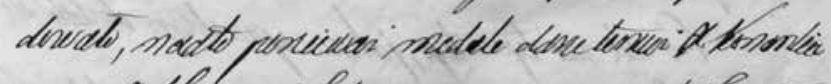

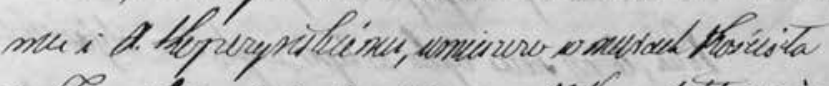

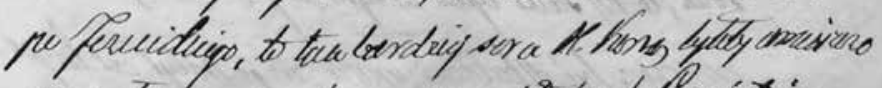

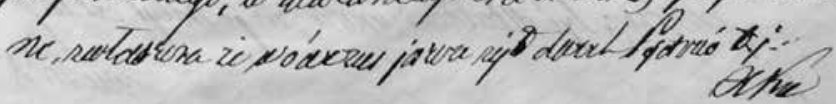

13. List Franciszka Kasterskiego do rektora Adama Słotwińskiego z 24 stycznia 1882 roku. W zbiorach Archiwum Polskiej Prowincji Zakonu Pijarów w Krakowie. Fot. Ryszard Mączyński 


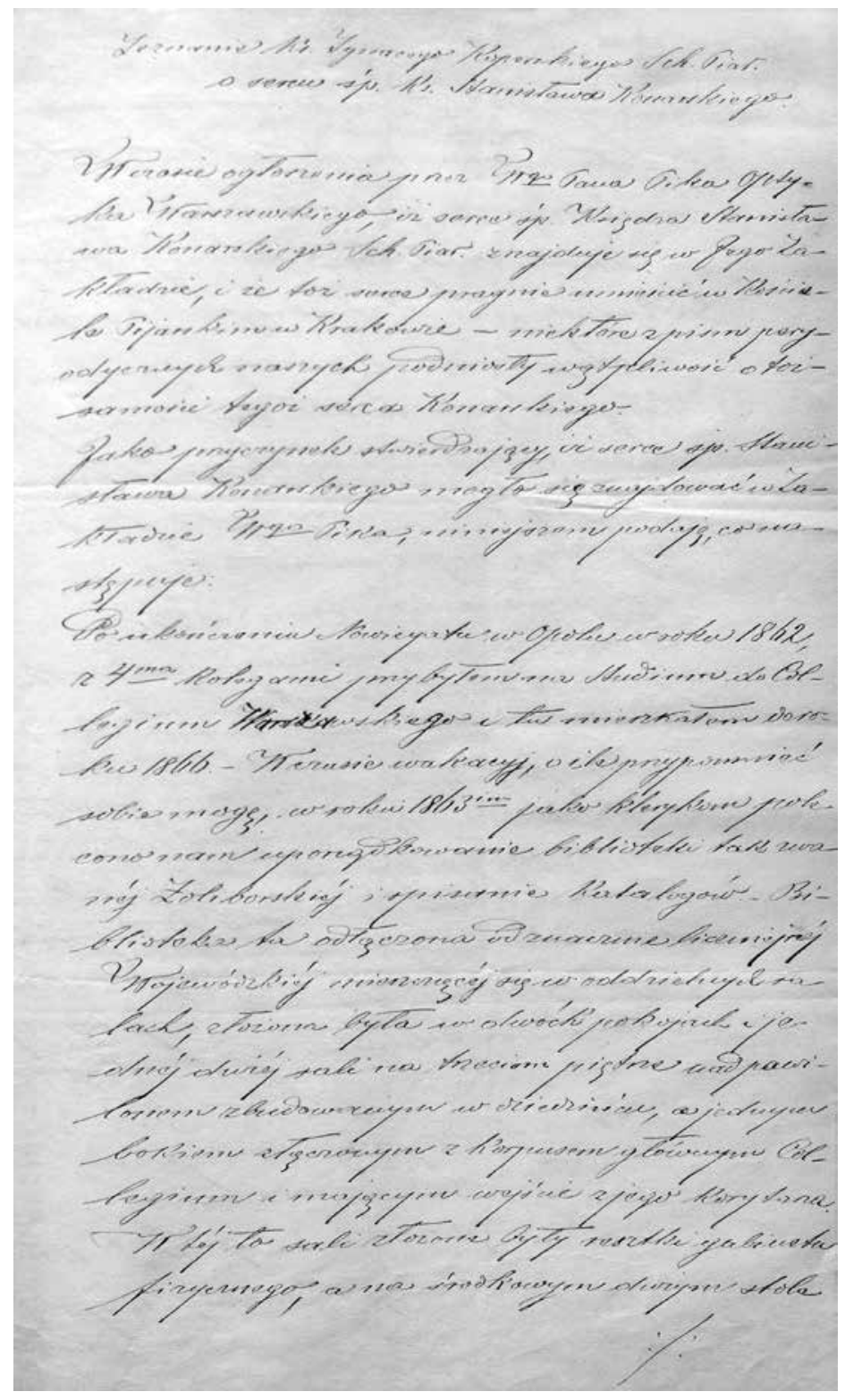

14. Zeznanie Ignacego Koperskiego z 9 lutego 1885 roku. W zbiorach Archiwum Polskiej Prowincji Zakonu Pijarów w Krakowie. Fot. Ryszard Mączyński 


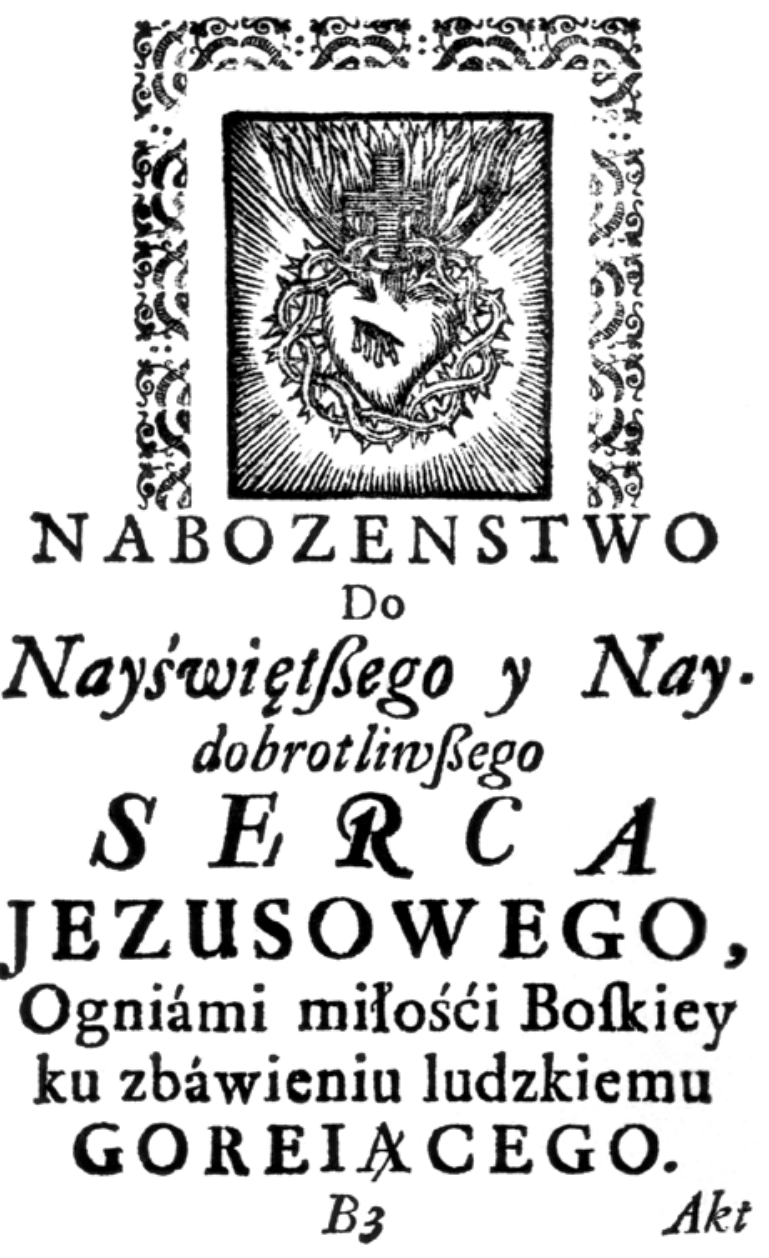

15. Karta z wizerunkiem Najświętszego Serca Jezusowego zamieszczona w dziele Paulina Wiązkiewicza Skarb nowy dotąd niewiadomych łask i nieznanych dobrodziejstw (1734).

Fot. Pracownia Reprograficzna Biblioteki Narodowej w Warszawie 


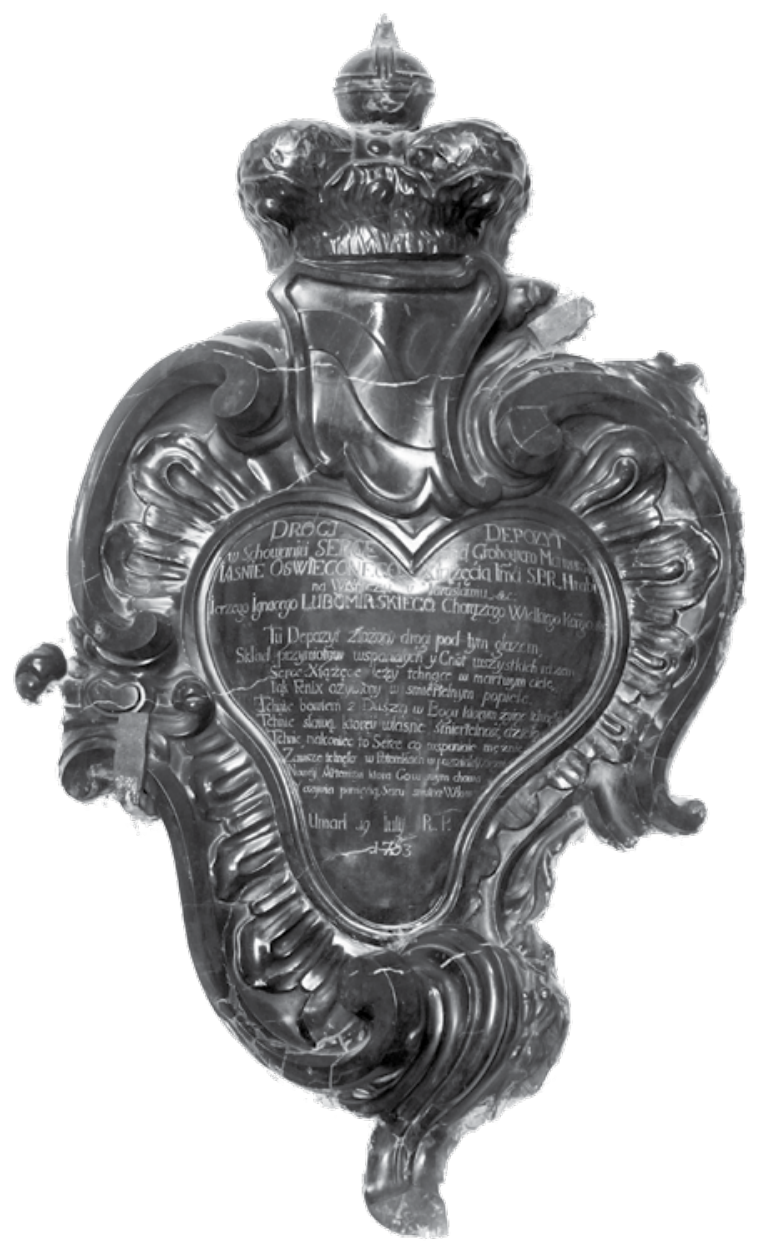

16. Rzeszów, kościół pijarów. Epitafium upamiętniające miejsce złożenia serca Jerzego Ignacego Lubomirskiego, pisarza polnego koronnego (1753). Fot. Tadeusz Późniak 


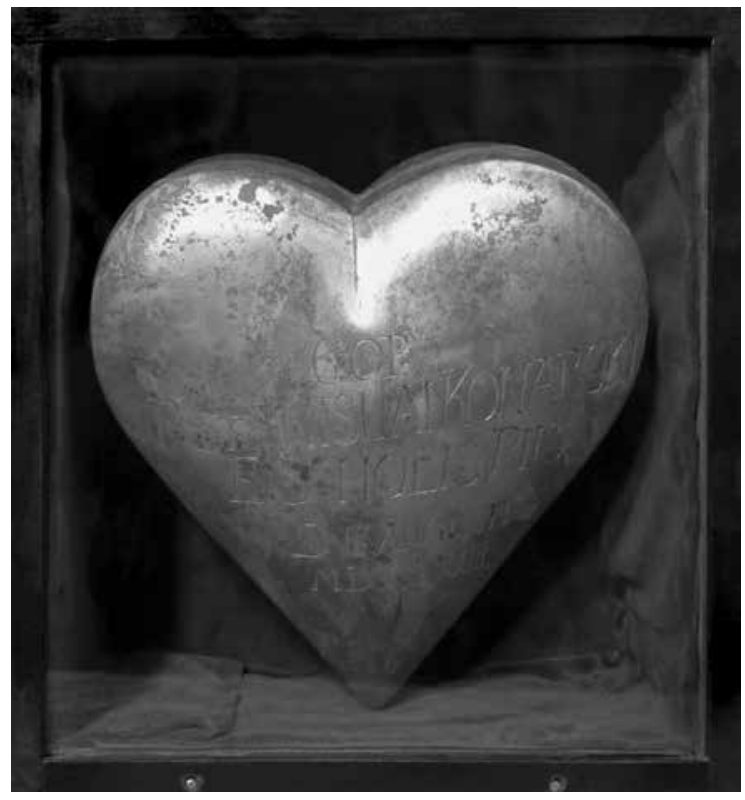

17. Kraków, kościół pijarów. Puszka z sercem Stanisława Konarskiego, obecny stan zachowania (2015). Fot. Ryszard Mączyński 